\title{
Anatomical variation of mesophyll conductance due to salt stress in Populus cathayana females and males growing under different inorganic nitrogen sources
}

\author{
Liu, Miao
}

2021-08

Liu , M , Liu , X , Du , X , Korpelainen , H , Niinemets , U \& Li , C 2021 , ' Anatomical variation of mesophyll conductance due to salt stress in Populus cathayana females and males growing under different inorganic nitrogen sources ', Tree Physiology, vol. 41 , no. 8 , pp. 1462-1478 . https://doi.org/10.1093/treephys/tpab017

http://hdl.handle.net/10138/339732

https://doi.org/10.1093/treephys/tpab017

acceptedVersion

Downloaded from Helda, University of Helsinki institutional repository.

This is an electronic reprint of the original article.

This reprint may differ from the original in pagination and typographic detail.

Please cite the original version. 


(n)

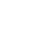

\title{
Anatomical variation of mesophyll conductance due to salt stress
} in Populus cathayana females and males growing under different inorganic nitrogen sources

\author{
Miao Liu ${ }^{1}$, Xiucheng Liu ${ }^{1}$, Xuhua $\mathrm{Du}^{2}$, \\ Helena Korpelainen ${ }^{3}$, Ülo Niinemets ${ }^{4,5}$, Chunyang Li $^{1, *}$
}

${ }^{1}$ College of Life and Environmental Sciences, Hangzhou Normal University, Hangzhou 311121, China

${ }^{2}$ Key Laboratory of State Forestry and Grassland Administration on Bamboo Resources and Utilization, China National Bamboo Research Center, State Forestry and Grassland Administration, Hangzhou 310012, China

${ }^{3}$ Department of Agricultural Sciences, Viikki Plant Science Centre, University of Helsinki, P.O. Box 27, FI-00014, Finland

${ }^{4}$ Institute of Agricultural and Environmental Sciences, Estonian University of Life Sciences, Kreutzwaldi 1, 51006 Tartu, Estonia

${ }^{5}$ Estonian Academy of Sciences, Kohtu 6, 10130 Tallinn, Estonia

* Corresponding author: Chunyang Li, E-mail address: $\underline{\text { licy@hznu.edu.cn }}$

Running title: Sexually different responses to salt and $\mathrm{N}$ forms 
Abstract Synergistic regulation in leaf architecture and photosynthesis is essential for salt tolerance. However, how plant sex and inorganic nitrogen sources alter salt stress-dependent photosynthesis remains unknown. Leaf anatomical characteristics and photosynthesis of Populus cathayana Rehder females and males were investigated under salt stress conditions combined with $\mathrm{NO}_{3}{ }^{-}$and $\mathrm{NH}_{4}{ }^{+}$supplies to clarify the underlying mechanisms. In salt-stressed females, we observed an increased mesophyll spongy cell density, a reduced chloroplast density, a decreased surface area of chloroplasts adjacent to the intercellular air space $\left(S_{\mathrm{c}} / S\right)$ and an increased mesophyll cell area per transverse section width $(S / W)$, consequently causing mesophyll conductance $\left(g_{\mathrm{m}}\right)$ and photosynthesis inhibition, especially under $\mathrm{NH}_{4}{ }^{+}$ supply. Conversely, males with a greater mesophyll palisade tissue thickness and chloroplast density, but a lower spongy cell density had lower $S / W$ and higher $S_{\mathrm{c}} / S$, and higher $g_{\mathrm{m}}$ and photosynthesis. $\mathrm{NH}_{4}{ }^{+}$-fed females had a lower $\mathrm{CO}_{2}$ conductance through cell wall and stromal conductance perpendicular to the cell wall, but a higher chloroplast conductance from the cell wall $\left(g_{\text {cyt1 }}\right)$ than females supplied with $\mathrm{NO}_{3}{ }^{-}$, while males had a higher chloroplast conductance and lower $\mathrm{CO}_{2}$ conductance through cell wall when supplied with $\mathrm{NO}_{3}{ }^{-}$instead of $\mathrm{NH}_{4}{ }^{+}$under salt stress. These findings indicate sex-specific strategies in coping with salt stress related to leaf anatomy and $g_{\mathrm{m}}$ under both types of $\mathrm{N}$ supplies, which may contribute to sex-specific $\mathrm{CO}_{2}$ capture and niche segregation. 
Keywords: Leaf anatomy, mesophyll conductance, $\mathrm{N}$ form, salt stress, sexual dimorphism

\section{Introduction}

Salt stress reduces plant biomass and crop production, and these changes are typically strongly correlated with a decreasing rate of photosynthesis (Praxedes et al. 2010, Wankhade et al. 2013). Photosynthesis is a critical factor that determines energy conversion efficiency, thereby regulating plant productivity and performance (Pinheiro and Chaves 2011, Ort et al. 2015). It has been suggested that $\mathrm{CO}_{2}$ stomatal limitations, including stomatal $\left(g_{\mathrm{s}}\right)$ and mesophyll $\left(g_{\mathrm{m}}\right)$ conductance limitation, are primary factors restricting leaf photosynthesis $(A)$ in salt-stressed leaves (Flexas et al. 2016, Zait et al. 2019, Veromann-Jürgenson et al. 2020). Leaf dehydration induced by drought and/or salt stress reduces $g_{s}$ to control the transpirational water flow from leaves (Golldack et al. 2014). However, lower $g_{\mathrm{s}}$ reduces $\mathrm{CO}_{2}$ flux into leaves, and then results in the limitation of $A$ and carbon starvation in plants. The $g_{\mathrm{m}}$ value indicates $\mathrm{CO}_{2}$ diffusion from the sub-stomatal cavities to the sites of carboxylation. According to a previous simulation performed by Zhu et al. (2010), doubling of $g_{\mathrm{m}}$ could improve photosynthetic rates by nearly $20 \%$ under normal growth conditions. In stressed plants, the photosynthetic limitation due to $g_{\mathrm{m}}$ can be much greater than in non-stressed plants (Martins et al. 2014, Niinemets and Keenan 2014). Therefore, it is important to clarify, whether and how salt stress affects $g_{\mathrm{m}}$ and then leaf $A$ in dioecious plants. 
The $g_{\mathrm{m}}$ values of given genotypes or species are associated with changes in leaf anatomical traits, especially under environmental stresses (Niinemets et al. 2009a, Lu et al. 2016). Generally, leaves with a robust structure and higher $L M A$ show lower $g_{\mathrm{m}}$ and photosynthesis (Niinemets et al. 2009b, Tomás et al. 2013). Plants with higher LMA usually have a greater biomass investment in supporting tissues, thicker cell walls, a lower cytoplasm and higher stroma conductance to $\mathrm{CO}_{2}$ diffusion inside leaves (Niinemets 2007, Tomás et al. 2013). Inside a leaf, $\mathrm{CO}_{2}$ from substomatal cavities diffuses through the intercellular air space and liquid phase consisting of the cell wall, cytoplasm, plasma membrane, chloroplast stroma and envelope (Tosens et al. 2012b, Cano et al. 2013). The $\mathrm{CO}_{2}$ liquid-phase resistance accounts for $80-90 \%$ of mesophyll resistance (Lu et al. 2016, Tosens et al. 2016).

Among $\mathrm{CO}_{2}$ liquid-phase diffusion components, the cell wall thickness of the leaf mesophyll and the chloroplast surface area exposed to intercellular air space $\left(S_{\mathrm{c}} / S\right)$ have been considered as the strongest limiting factors of $g_{\mathrm{m}}$, but these traits are highly different among species (Tomás et al. 2013, Berghuijs et al. 2016). An increased mesophyll cell wall thickness and decreased $S_{\mathrm{c}} / S$ can probably increase the $\mathrm{CO}_{2}$ diffusion path length and area, which will limit $g_{\mathrm{m}}$ in plants (Terashima et al. 2011, Tomás et al. 2013). In addition, the increased mesophyll surface area exposed to the intercellular air space $\left(S_{\mathrm{m}} / S\right)$ facilitates $\mathrm{CO}_{2}$ diffusion from the cytosol into chloroplasts, which promotes photosynthesis via greater $\mathrm{g}_{\mathrm{m}}$ (Ren et al. 2019, Hu et al. 
2020). Other cellular components, such as chloroplasts, plasmalemma and cytoplasm also affect $\mathrm{CO}_{2}$ diffusion into leaves (Tomás et al. 2013, Lu et al. 2016). A higher mesophyll cell density typically decreases the air space size, which probably decreases the $\mathrm{CO}_{2}$ gas-phase conductance (Tomás et al. 2013, Lu et al. 2016). Also, a recent study has indicated that a large total mesophyll cell area per transverse section width $(S / W)$ is advantageous as balancing the leaf structure and $\mathrm{CO}_{2}$ assimilation $(\mathrm{Hu}$ et al. 2020). Therefore, knowledge of leaf structural and anatomical traits affecting $g_{\mathrm{m}}$ is crucial for understanding photosynthetic efficiency, especially under abiotic stresses.

Generally, salt stress induces leaf dehydration and leads to the reduction of $g_{\mathrm{m}}$ and $g_{\mathrm{s}}$ in plants (Wang et al. 2018, Zait et al. 2019). Leaf dehydration reduces the internal air space volume and increases the cell wall thickness (Henry et al. 2000, Tosens et al. 2012a). The size and shape of chloroplasts and mesophyll cells are also strongly affected by leaf dehydration (Scoffoni et al. 2017). Such changes probably have major implications for $g_{\mathrm{m}}$ (Tosens et al. 2012a) and suggest that salt stress may lead to analogous changes. How $g_{\mathrm{m}}$ is affected by salinity is still an open question, especially in trees. Moreover, little is known about the effects of salt stress on leaf anatomy and photosynthesis under different inorganic $\mathrm{N}$ sources, e.g. $\mathrm{NH}_{4}{ }^{+}$vs. $\mathrm{NO}_{3}{ }^{-}$.

Poplars are dioecious species, in which females and males have significant differences in biomass partitioning, photosynthesis, carbon-nutrient balance and leaf anatomical 
traits when exposed to abiotic stresses, including salt stress (Li et al. 2016, Chen et al. 2016, Liu et al. 2020a, Liu et al. 2021), which is further affected by $\mathrm{N}$ forms (Chen et al. 2011, Liu et al. 2020b). Poplars preferentially take up $\mathrm{NO}_{3}{ }^{-}$when both $\mathrm{NH}_{4}{ }^{+}$and $\mathrm{NO}_{3}{ }^{-}$are given at the same concentration, and growth may be accelerated despite high energy requirements (Bi et al. 2020). Energy costs do not differ between $\mathrm{NO}_{3}{ }^{-}$and $\mathrm{NH}_{4}{ }^{+}$when the assimilation of $\mathrm{NO}_{3}{ }^{-}$occurs in the shoots, especially under abiotic stress (Guo et al. 2007). Interestingly, poplar females have a higher specific root length (SRL), which indicates a lower carbon cost but a weaker root exploration capacity compared to males, while lower SRL in males may facilitate the utilization of less-mobile $\mathrm{NH}_{4}{ }^{+}$(Xia et al. 2020). Sex- and $\mathrm{N}$ form-dependent root system architecture investments largely reflect energy requirement for foliage construction and, thereby, may affect $g_{\mathrm{m}}$ and photosynthesis. Niinemets (1999) has proposed that the fraction of the annual biomass invested in foliage decreases in older trees, which results from biomass being largely invested in roots and stems. As discussed above, we hypothesize that $\mathrm{N}$ forms affect root biomass allocation with further modifications of leaf anatomy and $g_{\mathrm{m}}$.

In this study, we employ Populus cathayana to examine sex-specific adaptive strategies to salt stress under $\mathrm{NO}_{3}{ }^{-}$and $\mathrm{NH}_{4}{ }^{+}$supplies with the following hypotheses: (1) sex-specific trade-offs between leaf anatomical properties and $g_{\mathrm{m}}$ determine sex-specific differences in salt adaptation; (2) $\mathrm{N}$ forms affect root energy allocation, with further modifications in leaf anatomy and $g_{\mathrm{m}}$ under salt stress in a sex-dependent 
132

133

manner. This study will not only help us to improve understanding of the response of foliar architecture to photosynthesis under salt stress and different $\mathrm{N}$ forms, but it will aid to predict photosynthetic behaviour in tree species with different $\mathrm{N}$ source preferences and spatiotemporal changes in $\mathrm{N}$ assimilation at rising atmospheric $\mathrm{CO}_{2}$.

\section{Materials and methods}

\section{Plant material and experimental design}

Cuttings of $P$. cathayana were obtained from different trees of each sex from populations in riparian and valley flat habitats of the Qinghai Province, China $\left(30^{\circ} 67^{\prime}\right.$ $\mathrm{N}, 104^{\circ} 06^{\prime} \mathrm{E}$ ), as explained in detail by Liu et al. (2020a). The cuttings were planted in March 2019 at the Hangzhou Normal University, China, (30 $\left.01^{\prime} \mathrm{N}, 104^{\circ} 07^{\prime} \mathrm{E}\right)$. The seedlings were cultivated in a semi-controlled greenhouse with a daytime temperature of $21-25{ }^{\circ} \mathrm{C}$, a night-time temperature of $15-18{ }^{\circ} \mathrm{C}$, a photoperiod of 12-14 h, and a relative humidity of $76-81 \%$ throughout the growth period. After growing for 5 weeks, 32 uniform and healthy seedlings (16 females and 16 males) with heights of 30-40 $\mathrm{cm}$ were transplanted into $10-1$ plastic pots with a $10-\mathrm{kg}$ mixture of sand, vermiculite and perlite $(1: 1: 1)$.

The experiment was completely randomized with two sexes (males, females), two $\mathrm{N}$ regimes $\left(\mathrm{NO}_{3}{ }^{-}, \mathrm{NH}_{4}{ }^{+}\right)$, and two $\mathrm{NaCl}$ levels $(-\mathrm{NaCl},+\mathrm{NaCl})$. Each treatment was 
replicated four times. The plants were fertilized every 2 days with $200 \mathrm{ml}$ nutrient solution $(\mathrm{pH}=6.0)$ containing either $3.75 \mathrm{mM} \mathrm{NH}_{4}^{+}$or $3.75 \mathrm{mM} \mathrm{NO}_{3}^{-}$as the $\mathrm{N}$ source (see Table S1 for the full composition of nutrient solutions). After the seedlings had grown for a further 30 days, half of the cuttings were treated with $200 \mathrm{ml} \mathrm{NaCl}$ (200 mM) administered every day until the final $\mathrm{NaCl}$ concentration reached $50 \mathrm{mM}$ $\mathrm{kg}^{-1}$ growth substrate. Each day, the control cuttings received the same amount of distilled water.

\section{Gas exchange and fluorescence measurements}

Chlorophyll fluorescence and gas exchange characteristics of mature leaves were measured with a portable photosynthesis measuring system (Ll-6400; Li-Cor Inc., Lincoln, NE, USA) equipped with an integrated leaf chamber fluorometer (LI-6400-40). The measurements were conducted between 09:00 $\mathrm{h}$ and 16:30 h. The standard environmental conditions during measurements of leaf photosynthetic characteristics were as follows: leaf temperature of $25^{\circ} \mathrm{C}$, saturating photon quantum flux density (PPFD) of $1200 \mu \mathrm{mol} \mathrm{m} \mathrm{m}^{-2} \mathrm{~s}^{-1}$ (with 90\% red light and $10 \%$ blue light), relative humidity of $75 \%$, air flow rate of $500 \mu \mathrm{mol} \mathrm{s}^{-1}$ and $\mathrm{CO}_{2}$ concentration in the cuvette $\left(C_{\mathrm{a}}\right)$ of $400 \mu \mathrm{mol} \mathrm{mol}{ }^{-1}$. After leaf gas exchange rates stabilized, typically in 20-30 min, the steady-state fluorescence yield $\left(F_{\mathrm{s}}\right)$ was recorded, and a saturating light flash of $8000 \mu \mathrm{mol} \mathrm{m} \mathrm{m}^{-2} \mathrm{~s}^{-1}$ for $0.8 \mathrm{~s}$ was given to measure the maximum fluorescence yield at the light-adapted state $\left(F_{\mathrm{m}}{ }^{\prime}\right)$. For measurements of chlorophyll 
176 fluorescence, leaves were adapted to the dark for 30 min using an aluminium foil 177 cover. The minimum fluorescence $\left(F_{\mathrm{o}}\right)$ and maximum fluorescence $\left(F_{\mathrm{m}}\right)$ were 178 measured. After these measurements, $\mathrm{CO}_{2}$ response curves were measured with $C_{\mathrm{a}}$ 179 lowered stepwise from 400 to $300,200,100$ and $50 \mu \mathrm{mol} \mathrm{mol}^{-1}$, and then raised from 18050 to $400,600,800$ and $1000 \mu \mathrm{mol} \mathrm{mol}^{-1}$, while all other environmental conditions 181 were maintained. The chlorophyll fluorescence characteristics, $F_{\mathrm{S}}$ and $F_{\mathrm{m}}$ ', were also 182 measured at each $C_{\mathrm{a}}$.

Estimation of $g_{m}$ by chlorophyll fluorescence and gas exchange

Genty et al. (1989):

$$
\Phi_{\mathrm{PSII}}=\left(F_{\mathrm{m}}{ }^{\prime}-F_{\mathrm{s}}\right) / F_{\mathrm{m}}{ }^{\prime}(1)
$$

The electron transport rate from chlorophyll fluorescence $(J)$ was calculated as 192 follows:

$$
J=\Phi_{\mathrm{PSII}} \cdot Q \cdot \alpha \cdot \beta(2)
$$
absorptance) is obtained from the correlation between photosynthetic rate $(A)$ and $Q$ 
- $\Phi_{\mathrm{PSII}} / 4$ using the light response curve under non-photorespiratory conditions $\left(\left[\mathrm{O}_{2}\right]<\right.$ 1.0\%) (Yin et al. 2009). The light response curve under low $\left[\mathrm{O}_{2}\right]$ was measured based on the method of Lu et al. (2016). $Q$ is PPFD.

The $\mathrm{CO}_{2}$ response curves were used to estimate $g_{m}$ according to the variable $J$ method proposed by Harley et al. (1992); $g_{\mathrm{m}}$ was calculated as follows:

$$
g_{\mathrm{m}}=\frac{A}{C_{\mathrm{i}}-\frac{\Gamma^{*}\left(J+8\left(A+R_{\mathrm{d}}\right)\right)}{J-4\left(A+R_{\mathrm{d}}\right)}}
$$

where $R_{\mathrm{d}}$ is the dark respiration rate continuing in light, and $\Gamma^{*}$ is the hypothetical $\mathrm{CO}_{2}$ compensation point in the absence of $R_{\mathrm{d}}$ (Bernacchi et al. 2001, Tosens et al. $2012 \mathrm{~b}$ ). Then, $g_{\mathrm{m}}$ was used to transform $A / C_{\mathrm{i}}$ response curves into $A / C_{\mathrm{c}}$ response curves by the equation $C_{\mathrm{c}}=C_{\mathrm{i}}-A / g_{\mathrm{m}}$ and $\Gamma^{*}=C_{\mathrm{i}}{ }^{*}+R_{\mathrm{d}} / g_{\mathrm{m}}$. $C_{\mathrm{c}}$ was used to calculate the maximum velocity of carboxylation and the photosynthetic electron transport according to the method of Bernacchi et al. (2002). Each $g_{\mathrm{m}}$ was replicated four times for every specimen. $R_{\mathrm{d}}$ and $\mathrm{Ci}^{*}$ were measured according to Brooks and Farquhar (1985). Briefly, the $A / C_{\mathrm{i}}$ curve was generated at PPFD of 150,300 and $600 \mu \mathrm{mol} \mathrm{m}{ }^{-2}$ $\mathrm{s}^{-1}$, with each having four $C_{\mathrm{a}}$ chambers $\left(50,75,100\right.$ and $\left.150 \mu \mathrm{mol} \mathrm{CO} \mathrm{mol}^{-1}\right)$. The x-axis and y-axis of the intersection point of three $A / C_{\mathrm{i}}$ curves represented $C_{\mathrm{i}}^{*}$ and $R_{\mathrm{d}}$, respectively.

\section{Estimation of leaf construction costs}


221 Leaf construction costs [CC, g glucose (g dry mass $\left.)^{-1}\right]$ were calculated from ash [g $222 \mathrm{~g}^{-1}$ (d.m.)], $\mathrm{N}\left[\mathrm{g} \mathrm{g}^{-1}\right.$ (d.m.) $]$ and $H_{\mathrm{c}}\left[\mathrm{kJ} \mathrm{g}^{-1}\right.$ (d.m.)] according to Williams et al. (1987):

$$
\mathrm{CC}=\left\{\left[\left(0.06968 \times H_{\mathrm{c}}-0.065\right)(1-\mathrm{ash})\right]+[(\mathrm{K} \times \mathrm{N} / 14.0067)(180.15 / 24)]\right\} / 0.89(4)
$$

where $\mathrm{K}$ is the substrate of nitrogen oxidation state, +5 for nitrate and -3 for ammonium. $H_{\mathrm{c}}$ is the ash-free heat of combustion.

Microscopic observations and anatomical measurements

Leaf segments $(1 \times 1 \mathrm{~mm})$ were taken from leaves avoiding major veins, and fixed in a formaldehyde, acetic acid and alcohol solution (1:1:8 v/v) under vacuum for $20 \mathrm{~min}$. Thereafter, the samples were thoroughly washed three times with deionized water and dehydrated in a graded ethanol series. Sections were embedded in glycol methacrylate under vacuum. Semi-thin cross-sections were stained with safranin-fast green and viewed under a light microscope (Nikon Corporation, Kyoto, Japan) at 20× magnification. The following characteristics were measured from light micrographs: 238 the thickness, size and density of leaf palisade and spongy tissues, and the sum of 239 spongy and palisade tissue cell area per transverse section. 
242

$$
S_{\mathrm{m}} / S=\frac{L_{c}}{L_{\mathrm{mes}}} S_{\mathrm{m}} / S(6)
$$


where $L_{\mathrm{c}}$ and $L_{\mathrm{m}}$ are the distances of the chloroplast surface area and the mesophyll cells facing the intercellular air space, respectively; $W$ is the width of the measured section; and $F$ is the cell curvature correction factor, which is calculated according to the method of Thain et al. (1983). The values of $F$ ranged from 1.4-1.5 for palisade cells and 1.16-1.4 for spongy cells.

The fraction of intercellular air space $\left(f_{\text {ias }}\right)$ in leaf mesophyll, $f_{\text {ias }}$ was estimated as:

where $t_{\mathrm{mes}}$ is mesophyll thickness.

$$
f_{\text {ias }}=1-\frac{\sum S_{\mathrm{s}}}{t_{\text {mes }} W}(7)
$$

All parameters were analysed at three different fields and at three different sections. The weighted average was calculated based on tissue volume fractions according to Tomás et al. (2013).

Determination of leaf area, leaf dry mass per unit area, and leaf sodium content

Leaf samples were washed three times with deionized water and dried at $75{ }^{\circ} \mathrm{C}$ to a constant mass. Dry samples were ground and digested with $3: 1(\mathrm{v} / \mathrm{v}) \mathrm{HNO}_{3}$ and $\mathrm{HClO}_{4}$. Na concentration was determined using inductively coupled plasma mass spectrometry (Agilent 7500a, Agilent Technologies, CA, USA). 
Quantitative photosynthetic limitation analysis

A quantitative limitation analysis was used to distribute the relative controls on $A$

$$
\frac{\mathrm{d} A}{A}=S_{\mathrm{L}}+M C_{\mathrm{L}}+B_{\mathrm{L}}=l_{\mathrm{s}} \frac{\mathrm{d} g_{\mathrm{sc}}}{g_{\mathrm{sc}}}+l_{\mathrm{mc}} \frac{\mathrm{d} g_{\mathrm{m}}}{g_{\mathrm{m}}}+l_{\mathrm{b}} \frac{\mathrm{d} V_{\mathrm{cmax}}}{V_{\mathrm{cmax}}}(8)
$$

295

$$
l_{\mathrm{s}}=\frac{g_{\text {tot }} / g_{\mathrm{s}} \cdot \partial A / \partial C_{\mathrm{c}}}{g_{\text {tot }}+\partial A / \partial C_{\mathrm{c}}}(9)
$$

297

298

$$
l_{\mathrm{m}}=\frac{g_{\mathrm{tot}} / g_{\mathrm{m}} \cdot \partial A / \partial C_{\mathrm{c}}}{g_{\mathrm{tot}}+\partial A / \partial C_{\mathrm{c}}}(10)
$$

299

300

$$
l_{\mathrm{b}}=\frac{g_{\text {tot }}}{g_{\text {tot }}+\partial A / \partial C_{\mathrm{c}}}(11)
$$

301

302

303

304

305

306

$$
g_{\text {tot }}=\frac{1}{1 / g_{\mathrm{sc}}+1 / g_{\mathrm{m}}}
$$


308

309

310

311

312

313

314

315

316

317

318

319

320

321

322

323 where $\mathrm{g}_{\mathrm{m}}^{\mathrm{ref}}, g_{\mathrm{sc}}^{\mathrm{ref}}, A_{\mathrm{max}}^{\mathrm{ref}}$ and $V_{\mathrm{cmax}}^{\mathrm{ref}}$ are the reference (maximum) values of $g_{\mathrm{m}}, g_{\mathrm{sc}}, A$

324 and $V_{\mathrm{cmax}}$, respectively (Grassi and Magnani 2005). The reference values for $A, g_{\mathrm{sc}}, g_{\mathrm{m}}$

325 and $V_{\text {cmax }}$ correspond to $\mathrm{NO}_{3}{ }^{-}$and $\mathrm{NH}_{4}{ }^{+}$treatments without salt stress.

$$
\frac{d A}{A} \approx \frac{A_{\max }^{\mathrm{ref}}-A}{A_{\max }^{\mathrm{ref}}}(13)
$$

$$
\frac{d g_{\mathrm{m}}}{g_{\mathrm{m}}} \approx \frac{g_{\mathrm{m}}^{\mathrm{ref}}-g_{\mathrm{m}}}{g_{\mathrm{m}}^{\mathrm{ref}}}
$$

$$
\frac{d V_{\mathrm{cmax}}}{V_{\mathrm{cmax}}} \approx \frac{V_{\max }^{\mathrm{ref}}-V_{\mathrm{cmax}}}{V_{\mathrm{cmax}}^{\mathrm{ref}}}
$$

$$
\frac{d g_{\mathrm{sc}}}{g_{\mathrm{sc}}} \approx \frac{g_{\mathrm{sc}}^{\mathrm{ref}}-g_{\mathrm{sc}}}{g_{\mathrm{sc}}^{\mathrm{ref}}}
$$

326

327 The $\mathrm{CO}_{2}$ liquid-phase diffusion conductance in cytosol, cell wall and stromal 
conductance were calculated according to a general formula:

$$
g_{\mathrm{i}}=\frac{1}{r_{\mathrm{i}}}=\frac{r_{\mathrm{f}, 1} \cdot D_{\mathrm{w}} \cdot p_{\mathrm{i}}}{\Delta L_{\mathrm{i}}}(17)
$$

where $g_{\mathrm{i}}$ denotes the individual component conductance $\left(r_{\mathrm{i}}\right.$ is the $\mathrm{CO}_{2}$ liquid-phase diffusion resistance), and $D_{\mathrm{w}}, p_{\mathrm{i}}\left(\mathrm{m}^{3} \mathrm{~m}^{-3}\right)$ and $\Delta L_{\mathrm{i}}(\mathrm{m})$ are the $\mathrm{CO}_{2}$ aqueous-phase diffusion coefficient $\left(1.79 \times 10^{-9} \mathrm{~m}^{2} \mathrm{~s}^{-1}\right.$ at $\left.25^{\circ} \mathrm{C}\right)$, effective porosity for the given diffusion pathway component and the length of the diffusion path in the corresponding diffusion component, respectively. The dimensionless factor $r_{\mathrm{f}, 1}$ considers the reduction of diffusion in different cellular components due to the presence of solutes and macromolecules; $r_{\mathrm{f}, 1}$ was taken as 0.3 for cytosol and stroma, and 1.0 for cell walls (Niinemets and Reichstein 2003, Rondeau-Mouro et al. 2008). The effective porosity was 1.0 for stroma and cytosol. The $p_{\text {i }}$ value of the cell wall was estimated by a least-squares iterative analysis to obtain the best fit between the modelled and measured $g_{\mathrm{m}}$ values (Tosens et al. 2012b, Tomás et al. 2013). The $p_{\mathrm{i}}$ value of the cell wall was set at 0.3 for the thinnest cell walls and 0.028 for the thickest cell walls (Nobel 1991, Tosens et al. 2012b). In this study, the conductance of the chloroplast envelope ( $\left.g_{\text {env }}\right)$ and plasma membrane $\left(g_{\mathrm{pl}}\right)$ was set to $0.0035 \mathrm{~m} \mathrm{~s}^{-1}$ (Tosens et al. 2012a).

The total liquid-phase conductance consisted of two parallel pathways and was calculated as follows (Tomás et al. 2013): 


$$
g_{\text {liq }}=\frac{S_{\mathrm{c}}}{\left(r_{\mathrm{cw}}+r_{\mathrm{pl}}+r_{\mathrm{cel}, 1)}\right)}+\frac{S_{\mathrm{m}}-S_{\mathrm{c}}}{\left(r_{\mathrm{cw}}+r_{\mathrm{pl}}+r_{\mathrm{cel}, 2}\right)}
$$

352

353 where $r_{\mathrm{cw}}, r_{\mathrm{pl}}, r_{\mathrm{cel}, 1}$, and $r_{\mathrm{cel}, 2}$ are the resistances of cell wall, plasma membrane, cell

354 wall parts with chloroplasts and the interchloroplastial areas, respectively (Tomás et al.

355 2013). The $r_{\mathrm{cel}, 1}$ and $r_{\mathrm{cel}, 2}$ were calculated as follows:

356

357

358

359

360

361

362

363

364

365

366

367

368

369

370

371

$$
g_{\mathrm{cel}, 1}=\frac{1}{r_{\mathrm{cyt}, 1}+r_{\mathrm{env}}+r_{\mathrm{st}, 1}}
$$

$$
g_{\mathrm{cel}, 2}=\frac{1}{r_{\mathrm{cyt}, 2}+r_{\mathrm{env}}+r_{\mathrm{st}, 2}}(20)
$$

where $r_{\mathrm{st}, 1}$ and $r_{\mathrm{st}, 2}$ are the stromal resistance perpendicular and parallel to the cell walls, respectively. The $r_{\text {cyt, } 1}$ value is defined as the $\mathrm{CO}_{2}$ resistance through the plasmalemma inner surface to the outer surface of chloroplasts, and $r_{\mathrm{cyt}, 2}$ as the resistance from interchloroplastic cell wall portions to the outer surface of chloroplasts (Tomás et al. 2013). These equations give $g_{\mathrm{m}}$ in $\mathrm{m} \mathrm{s}^{-1}$. The conversion to molar units is given as follows:

$g_{\mathrm{m}}\left[\mathrm{mol} \mathrm{m} \mathrm{s}^{-1}\right]=\mathrm{g}_{\mathrm{m}}\left[\mathrm{m} \mathrm{s}^{-1}\right] 44.6[273.16 /(273.16+T)(P / 101325)]$, where $T$ is leaf temperature in ${ }^{\circ} \mathrm{C}$ and $P$ is air pressure in $\mathrm{Pa}$. 
373 The quantitative contributions of different anatomical traits to $g_{\mathrm{m}}$ were separated 374 according to Tosens et al. (2012b) and Tomás et al. (2013). The share of $g_{\mathrm{m}}$ in the gas 375 phase was calculated as follows:

376

377

378

379 The limitations of $g_{m}$ by different liquid-phase components $\left(l_{\text {i }}\right.$, where i stands for a 380 diffusion pathway component, including cell wall, cytosol, chloroplast stroma, chloroplast envelope and plasmalemma) were calculated as follows:

$$
l_{\mathrm{i}}=\frac{g_{\mathrm{m}}}{g_{\mathrm{i}} \frac{S_{\mathrm{m}}}{S}}(22)
$$

where $g_{\mathrm{i}}$ is the corresponding $\mathrm{CO}_{2}$ conductance of the diffusion pathway.

\section{Estimation of $g_{m}$ by a curve-fitting method}

Estimation of $g_{\mathrm{m}}$ was performed by the method of Ethier and Livingston (2004). The $g_{\mathrm{m}}$ estimation was performed with the $A / C_{\mathrm{i}}$ curves with a non-rectangular hyperbola version of the Farquhar's biochemical model for leaf photosynthesis (Farquhar et al. 1980). The $g_{\mathrm{m}}$ value from the fitting of $A / C_{\mathrm{i}}$ and measured from combined gas exchange $\left(g_{\mathrm{m}}\right)$ and chlorophyll fluorescence measurements $\left(g_{\mathrm{m}}\right.$-gas exchange) were 
significantly correlated $\left(r^{2}=0.79, P<0.05\right.$; Figure S1).

\section{Statistical analyses}

Statistical analyses were conducted using the SPSS software (version 22.0). Before analyses of variance (ANOVAs), the data were checked for normality. The differences between mean values were compared by Duncan's tests at a significance level of $P<$ 0.05. Three-way analyses of variance were performed to examine the effects of sex, $\mathrm{N}$ forms and salt levels. Structural equation modeling was used to evaluate the indirect and direct relationships between leaf structure, biomass allocation, chloroplast exposed surface to leaf area ratio $\left(S_{\mathrm{c}} / S\right)$, mesophyll cell area per transverse section width $(S / W), \mathrm{CO}_{2}$ mesophyll conductance $\left(g_{\mathrm{m}}\right)$ and photosynthesis $(A)$. Before the construction of the structure equation modeling, we conducted a principal component analysis (PCA) to create the multivariate functional index due to the correlations among the factors within each group. The structural equation modeling analyses were performed using the R package "lavaan" v. 0.6-1 (Rosseel 2012).

\section{Results}

\section{Morphological and anatomical traits of leaves}

Salt stress significantly decreased leaf $A, g_{\mathrm{m}}, g_{\mathrm{s}}$, leaf area, leaf biomass, $F_{\mathrm{v}} / F_{\mathrm{m}}$, 
chlorophyll concentration, the rate of photosynthetic electron transport (J, Eq. 2) and $V_{\text {cmax }}$ in females and males grown under both $\mathrm{N}$ forms (except for $F_{\mathrm{v}} / F_{\mathrm{m}}$ under $\mathrm{NH}_{4}{ }^{+}$ supply and leaf biomass under both $\mathrm{N}$ forms in males). The salt effects were greater in females than in males (Figure 1; Table 1; Table S2). Salt stress increased leaf dry mass per unit area (LMA) and leaf thickness (Figure 1; Table 1). Compared with control conditions, salt stress increased $L M A$ by $37 \%$ and $59 \%$ in females, and by $21 \%$ and $16 \%$ in males under $\mathrm{NO}_{3}{ }^{-}$and $\mathrm{NH}_{4}{ }^{+}$supply, respectively. Leaf thickness increased by $59 \%$ and $56 \%$ in females, and by $26 \%$ and $19 \%$ in males by salt stress under $\mathrm{NO}_{3}{ }^{-}$and $\mathrm{NH}_{4}{ }^{+}$supply, respectively (Table 2). The leaf construction cost with salt stress exposure was slightly higher in males than in females under $\mathrm{NH}_{4}{ }^{+}$supply, but it was similar in both sexes under $\mathrm{NO}_{3}{ }^{-}$supply (Table 1). The leaf dark respiration rate $\left(R_{\mathrm{d}}\right)$ increased by salt stress, and the effect of salt stress on $R_{\mathrm{d}}$ was greater in females than in males under both $\mathrm{N}$ forms. Salt stress induced $R_{\mathrm{d}}$ more in females under $\mathrm{NO}_{3}{ }^{-}$ supply than under $\mathrm{NH}_{4}{ }^{+}$supply; there was no significant difference in $R_{\mathrm{d}}$ in males between the two $\mathrm{N}$ forms (Table S2). The SRL value in females was greater than that in males, and the increase in SRL was more significant under $\mathrm{NO}_{3}{ }^{-}$supply in males (Table 1). The contrary was true for root length density (RLD) under salt stress. The root biomass and the ratio of root to shoot were higher in females than in males with salt stress under both $\mathrm{N}$ forms (Table 1; Table S2).

The density of both mesophyll palisade and spongy tissue cells was higher in females than in males exposed to salt stress under both $\mathrm{N}$ forms (Table S2). The contrary was 
true for the thickness of palisade and spongy tissues. Palisade and spongy cells were denser in $\mathrm{NH}_{4}{ }^{+}$-fed females than in those supplied by $\mathrm{NO}_{3}{ }^{-}$under salt stress, while a higher density of palisade and spongy cells was found in males with $\mathrm{NO}_{3}{ }^{-}$supply under salt stress (Table S2). Leaf thickness, $f_{\text {ias }}, S_{\mathrm{m}} / S, S_{\mathrm{c}} / S$, and chloroplast density and length were higher in males than in females with salt stress under both $\mathrm{N}$ forms (Table 2). $\mathrm{NH}_{4}{ }^{+}$-fed males with salt stress had lower $S / W$ and chloroplast density but higher $f_{\text {ias }}$ under $\mathrm{NO}_{3}{ }^{-}$supply (Table 2). In contrast, there was no significant difference in leaf thickness, $S_{\mathrm{m}} / S, S / W$, or chloroplast density and length in females with salt stress under either $\mathrm{N}$ form, but $S_{\mathrm{c}} / S$ and $f_{\text {ias }}$ were lower under $\mathrm{NH}_{4}{ }^{+}$supply (Table 2 ). $T_{\mathrm{cw}}$, $T_{\text {chl, }} l_{\text {cyt }, 1}$ and $l_{\text {cyt }, 2}$ in salt-stressed plants were higher under $\mathrm{NO}_{3}{ }^{-}$and $\mathrm{NH}_{4}{ }^{+}$supply in both sexes compared with control plants (Figure 1; Table 2). In males, salt stress increased $T_{\mathrm{cw}}, T_{\mathrm{chl}}, l_{\mathrm{cyt}, 1}$ and $l_{\mathrm{cyt}, 2}$ by $23 \%, 15 \%, 43 \%$ and $20 \%$, respectively, under $\mathrm{NO}_{3}{ }^{-}$supply, and by $15 \%, 24 \%, 66 \%$ and $28 \%$, respectively, under $\mathrm{NH}_{4}{ }^{+}$supply (Table 2). In contrast, in females, $T_{\mathrm{cw}}, T_{\mathrm{chl}}, l_{\mathrm{cyt}, 1}$, and $l_{\mathrm{cyt}, 2}$ increased by $19 \%, 34 \%, 62 \%$ and $37 \%$, respectively, under $\mathrm{NO}_{3}{ }^{-}$supply, and by $29 \%, 40 \%, 32 \%$ and $39 \%$, respectively, under $\mathrm{NH}_{4}{ }^{+}$supply in salt-stressed plants (Table 2).

\section{Correlations of $g_{m}$ with physiological characteristics of leaves}

The net photosynthesis rate $(A)$ exhibited a significant positive correlation with $g_{\mathrm{m}}$ and $g_{\mathrm{s}}$ in both sexes under both $\mathrm{NO}_{3}{ }^{-}$and $\mathrm{NH}_{4}{ }^{+}$supply (Figure $2 \mathrm{a}, \mathrm{b}$ ). Under both $\mathrm{N}$ forms, $A$ at a given $g_{\mathrm{s}}$ and $g_{\mathrm{m}}$ was higher in males than in females irrespective of salt stress 
(Figure 2, $P<0.05$, Duncan's test), reflecting a greater photosynthetic capacity in males. With an increasing $\mathrm{Na}^{+}$concentration in leaves, $g_{\mathrm{m}}$ decreased significantly in both sexes, especially in males under $\mathrm{NH}_{4}^{+}$supply (Figure 2c). Both $g_{\mathrm{m}}$ and the $\mathrm{CO}_{2}$ drawdown from intercellular air space to chloroplasts $\left(C_{\mathrm{i}-} C_{\mathrm{c}}\right)$ decreased under salt stress, but the reductions were greater in females than in males, especially under $\mathrm{NH}_{4}{ }^{+}$ supply (Figure 2d).

\section{Correlations of $g_{m}$ with anatomical traits of leaves}

Strong positive correlations between $g_{\mathrm{m}}$ and $f_{\text {ias }}$ were observed in females and males under all treatments $\left(P<0.001\right.$, Duncan's test) (Figure 3a). In males, $f_{\text {ias }}$ decreased by salt stress more under $\mathrm{NO}_{3}{ }^{-}$than under $\mathrm{NH}_{4}{ }^{+}$supply, whereas lower $f_{\text {ias }}$ was observed under $\mathrm{NH}_{4}{ }^{+}$than under $\mathrm{NO}_{3}{ }^{-}$supply (Figure 3a). According to multiple regression analyses, $g_{\mathrm{m}}$ was positively associated with $S_{\mathrm{m}} / S$ and $S_{\mathrm{c}} / S$ in all treatments in both sexes $\left(P<0.001\right.$; Duncan's test, Figure 3b, c). At given $S_{\mathrm{m}} / S, g_{\mathrm{m}}$ was greater in males than in females, but a similar relationship between $g_{\mathrm{m}}$ and $S_{\mathrm{c}} / S$ was observed in both sexes (Figure 3b, c). A strong negative relationship was observed between $g_{\mathrm{m}}$ and $T_{\mathrm{cw}}$ in both sexes under both $\mathrm{N}$ forms $(P<0.001$; Duncan's test, Figure $3 \mathrm{~d})$. The slopes of $g_{\mathrm{m}}$ vs. $T_{\mathrm{cw}}$ were similar in males and females, but because salt stress led to higher $T_{\mathrm{cw}}$ in females than in males (see above), the $g_{\mathrm{m}}$ vs. $T_{\mathrm{cw}}$ line was shifted towards higher $T_{\mathrm{cw}}$ values along the common slope (Figure $3 \mathrm{~d}$ ). $S_{\mathrm{c}} / S$ and $\mathrm{T}_{\mathrm{cw}}$ better explained the sexually differential $g_{\mathrm{m}}$ relative to $f_{\text {ias }}$ and $S_{\mathrm{m}} / S$. In contrast, $f_{\text {ias }}$ and $S_{\mathrm{m}} / S$ explained the 
differences among treatments for each sex.

\section{Limitation of photosynthesis under salt stress}

According to the quantitative limitation analysis, salt stress changed the share of mesophyll, stomatal and biochemical limitations in both sexes under $\mathrm{NH}_{4}{ }^{+}$and $\mathrm{NO}_{3}{ }^{-}$ supply (Figure 4a). In particular, biochemical and mesophyll diffusion limitations (Eqs 10-11) restricted photosynthetic capacity more than stomatal limitations (Eq. 9) under salt stress (Figure 4a). Mesophyll diffusion limitations due to salt stress were higher in females than in males under both $\mathrm{N}$ forms, and the extent of inhibition due to salt stress was greater under $\mathrm{NH}_{4}{ }^{+}$than under $\mathrm{NO}_{3}{ }^{-}$supply (Figure 4a). Salt stress strongly increased biochemical limitations in females under both $\mathrm{N}$ forms, but the extent of such limitations was more significant in males under $\mathrm{NO}_{3}{ }^{-}$than under $\mathrm{NH}_{4}{ }^{+}$ supply. Stomatal limitations were higher under $\mathrm{NO}_{3}^{-}$than under $\mathrm{NH}_{4}^{+}$supply, especially in females (Figure 4a, $P<0.05$, Duncan's test). Positive relationships were observed between leaf $\mathrm{Na}$ and $S_{\mathrm{L}}$, and $\mathrm{Na}$ and $M C_{\mathrm{L}}$ in both sexes (Figure $4 \mathrm{~b}$ ).

\section{Limitations of $g_{m}$ resulting from diffusion pathway components}

In all cases, $\mathrm{CO}_{2}$ liquid phase diffusion represented a higher proportion of the total diffusion pathway limitation than did gas phase diffusion (Figure 5a-d). For the liquid phase, decreases in the absolute values of $\mathrm{CO}_{2}$ diffusion conductance due to salt stress 
504

were greater in females than in males under both $\mathrm{N}$ forms (Figure $5 \mathrm{~d}$ ). Moreover, the salt stress-dependent increase in the absolute liquid phase conductance was lower under $\mathrm{NH}_{4}{ }^{+}$than under $\mathrm{NO}_{3}{ }^{-}$supply in females but not in males (Figure $5 \mathrm{~d}$ ).

The analysis of different liquid phase components indicated that the chloroplast stroma and cytoplasm were the most limiting components in females and males (Figure 6a, b). In salt-stressed females, the share of overall limitation due to chloroplast stroma was reduced under $\mathrm{NH}_{4}{ }^{+}$but unaffected under $\mathrm{NO}_{3}{ }^{-}$supply. In contrast, salt stress increased the $\mathrm{CO}_{2}$ diffusion limitation due to cytoplasm in both sexes. Salt stress did not affect chloroplast stromal limitation under either $\mathrm{N}$ form in males (Figure $6 a, b)$. The limitation of liquid phase conductance due to cell walls was not affected by salt stress under either N supply in either sex. However, salt stress led to $43 \%$ and $109 \%$ increases in the relative chloroplast envelope limitation under $\mathrm{NO}_{3}{ }^{-}$ and $\mathrm{NH}_{4}^{+}$supply, respectively, in females, while the limitation of the chloroplast envelope did not change by salt stress in males under $\mathrm{NH}_{4}{ }^{+}$supply (Figure 6a, b).

The absolute values of diffusion conductance differed among sexes and treatments (Figure 6c, d). Salt stress decreased $g_{\text {cyt1 }}, g_{\text {cyt2 }}$ and $g_{\text {st } 1}$ in both sexes under $\mathrm{NO}_{3}{ }^{-}$and $\mathrm{NH}_{4}{ }^{+}$supply, and the effects of salt stress on cytoplasm conductance were greater in males than in females (Figure $6 \mathrm{c}, \mathrm{d}$; Figure S2). The $g_{\mathrm{st2}}$ value of females also decreased by salt stress under $\mathrm{NH}_{4}^{+}$supply, but there was no significant difference in males under either $\mathrm{N}$ form (Figure 6c, d; Figure S2). Compared with control 
526

527

528

529

530

531

532

533

534

535

536

537

538

539

540

541

542

543

544

545

546

547

conditions, salt stress had higher $g_{\mathrm{st} 1}$ and $g_{\mathrm{cw}}$, and lower $g_{\mathrm{cyt} 1}$ in females under $\mathrm{NO}_{3}{ }^{-}$ than under $\mathrm{NH}_{4}{ }^{+}$supply, whereas no significant differences were found in $g_{\mathrm{s} 22}$ and $g_{\mathrm{cyt} 2}$ values between the two $\mathrm{N}$ forms (Figure $\mathrm{S} 2$ ). In males, greater $g_{\mathrm{cw}}$ and $g_{\mathrm{st} 2}$, and lower $g_{\text {cyt1 }}$ and $g_{\text {cyt2 }}$ induced by salt stress were found under $\mathrm{NH}_{4}{ }^{+}$supply than under $\mathrm{NO}_{3}{ }^{-}$ supply (Figure 6c, d; Figure S2). There was no significant difference in $g_{\text {st1 }}$ between the two $\mathrm{N}$ forms in males.

\section{Structural equation modelling}

As shown in Figure 7, structural equation modelling suggested that leaf $S / W$ and $g_{\mathrm{m}}$ had direct effects on leaf photosynthesis $\left(r^{2}=-0.49\right.$ and 0.51 , respectively). The leaf photosynthesis was positively correlated with leaf $g_{\mathrm{m}}$ but negatively correlated with leaf $S / W$. Leaf $S_{\mathrm{c}} / S$ had a direct positive effect on $g_{\mathrm{m}}\left(r^{2}=0.41\right)$, while leaf $S / W$ had a direct negative effect on $g_{\mathrm{m}}\left(r^{2}=-0.60\right)$. Leaf structure had a direct positive effect on biomass allocation $\left(r^{2}=0.47\right)$ and $S / W\left(r^{2}=0.34\right)$, but a direct negative effect on $S_{\mathrm{c}} / S$ $\left(r^{2}=-0.30\right)$. By contrast, biomass allocation had a direct positive effect on $S_{\mathrm{c}} / S\left(r^{2}=\right.$ $0.36)$.

Schematic modes showing the sexual difference in $g_{\mathrm{m}}$

As shown in Figure 8, under salt stress, females had less chloroplast and more mesophyll spongy cells; the contrary was true for males under both $\mathrm{N}$ forms. The $\mathrm{CO}_{2}$ 
548

549

550

551

552

553

554

555

556

557

558

559

560

561

562

563

564

565

566

567

568

569

stroma $\left(g_{\mathrm{st}}\right)$ and cytoplasm conductance $\left(g_{\text {cyt }}\right)$ were the lowest among the $\mathrm{CO}_{2}$ liquid conductance levels. The $\mathrm{CO}_{2}$ cell wall conductance of females was lower with $\mathrm{NH}_{4}{ }^{+}$ supply, but lower with $\mathrm{NO}_{3}{ }^{-}$supply when compared to males under salt stress. The $g_{\text {st1 }}$ and $g_{\text {cyt1 }}$ values of males were higher than those of females under both $\mathrm{N}$ forms and salt stress. Under salt stress, $g_{\text {st2 }}$ was higher in females than in males with $\mathrm{NH}_{4}{ }^{+}$ supply, but it showed no significant difference between the sexes under $\mathrm{NO}_{3}{ }^{-}$supply. $\mathrm{NH}_{4}{ }^{+}$-fed females had greater $g_{\text {cyt1 }}$ but lower $g_{\text {st } 1}$ and $g_{\mathrm{cw}}$, and similar $g_{\mathrm{st} 2}$ and $g_{\mathrm{cyt} 2}$ than those under $\mathrm{NO}_{3}{ }^{-}$supply, while males had higher $g_{\text {cyt1 }}$ and $g_{\text {cyt2 }}$, lower $g_{\text {cw }}$ and $g_{\text {st2, }}$ and similar $g_{\text {st1 }}$ under $\mathrm{NO}_{3}{ }^{-}$supply than under $\mathrm{NH}_{4}{ }^{+}$supply under salt stress (Figure 8).

\section{Discussion}

The present study clearly demonstrated that salt stress imposes sex-specific restraints on $\mathrm{CO}_{2}$ assimilation, mainly deriving from the restraint of $g_{\mathrm{m}}$ relative to $g_{\mathrm{s}}$ under $\mathrm{NO}_{3}{ }^{-}$and $\mathrm{NH}_{4}{ }^{+}$supply. Generally, stomatal closure is the first response to salt stress in plants (Wang et al. 2018). Salt stress could disturb stomatal function, leading to a decreased photosynthetic capacity (Tavakkoli et al. 2011, Pérez-López et al. 2012, Chen et al. 2015). Improving stomatal regulation has been regarded as the most effective approach to alleviate salt stress in plants (Chen et al. 2015, Qiu and Katul 2020). In this study, both $g_{\mathrm{m}}$ and $g_{\mathrm{s}}$ were positively correlated with $A$ in females and males under both $\mathrm{N}$ forms (Figure 2). The relationship of $g_{\mathrm{m}}$ and $g_{\mathrm{s}}$ was stronger in 
571 significantly decreased by salt stress under both $\mathrm{N}$ forms, especially in females (Table

572 1; Table S2).

573 The variable $g_{\mathrm{m}}$ was the main limiting factor for the sexual difference in $A$ under salt

574 stress. This result was a little inconsistent with a previous study on Ziziphus 575 spina-christi trees suggesting that $g_{\mathrm{m}}$ plays a critical role in controlling $A$ only under 576 severe salinity stress (Zait et al. 2019). This could be explained by the different way 577 of calculating $l_{\mathrm{s}}$ and $l_{\mathrm{m}}$, as well as by the plant species. In the study by Zait et al. 578 (2019), the authors investigated drought-tolerant Ziziphus spina-christi trees, which 579 exhibited strong tolerance to salt stress. The concentration of $\mathrm{NaCl}$ used in our study 580 was moderate for males but not for females. In this study, the net photosynthetic rate $581 A$ and stomatal conductance $g_{\mathrm{s}}$ decreased by salt stress more significantly in Populus 582 cathayana females than in males. Additionally, $g_{\mathrm{s}}$ was dynamic and changed in 583 response to environmental conditions rapidly or even faster than $g_{\mathrm{m}}$ (Flexas et al. 584 2008). These results suggested that the photosynthetic limitation from $g_{\mathrm{m}}$ might be 585 higher than that from $g_{\mathrm{s}}$ under our experimental conditions.

587 Salt stress affects those morphological and anatomical traits of leaves that are 588 associated with $\mathrm{CO}_{2}$ diffusion into the leaves and leaf photosynthesis (Wankhade et al. 589 2013, Wang et al. 2018). A higher $L M A$ value is correlated with a greater dry mass 590 investment and it has a negative effect on $g_{\mathrm{m}}$ (Tomás et al. 2013, Onoda et al. 2017). 591 Consistently, females with higher $L M A$ had lower $g_{\mathrm{m}}$ under salt stress (Table 1). It is 
592

593

594

595

596

597

598

599

600

601

602

603

604

605

606

607

608

609

610

611

612

613

noteworthy that males with higher $A$ and $g_{\mathrm{m}}$ had higher $L M A$ than females, which suggested that it was not possible to precisely determine $g_{\mathrm{m}}$ and $A$ only from leaf $L M A$ (Figure 7), because of the effects of the chemical composition of leaves (John et al. 2017). The $S / W$ value included the total cell area of palisade and spongy tissues per transverse section width, representing the leaf structural investment per area, which would be a more advantageous and convenient trade-off between the leaf structure and photosynthesis (Hu et al. 2020). The results of the structural equation modelling suggested that $S / W$ plays a critical role in determining $g_{\mathrm{m}}$ and $A\left(r^{2}=-0.60\right.$ for $g_{\mathrm{m}}$ and -0.49 for $A$ ) (Figure 7). A lower chloroplast density and a greater mesophyll spongy density in females would reduce light energy capture and $\mathrm{CO}_{2}$ diffusion conductance in leaves, especially under $\mathrm{NH}_{4}{ }^{+}$supply (Table 2).

Cell wall thickness and chloroplast distribution are critical fort setting $g_{\mathrm{m}}$ limitation in plants (Terashima et al. 2011). Consistently, $S_{\mathrm{c}} / S$ and $T_{\mathrm{cw}}$ were those anatomical variables that best explain differences in $g_{\mathrm{m}}$ between sexes (Figures 3, 7, 8). A greater increase in chloroplast numbers observed in males compared to females facilitated an increase in $S_{\mathrm{c}} / S$ (Figure 8). Higher $S_{\mathrm{c}} / S$ and a lower cell wall thickness led to an increased $\mathrm{CO}_{2}$ diffusion conductance into male leaves, which was consistent with previous studies (Peguero-Pina et al. 2017, Wang et al. 2018). Indeed, the quantification of $g_{m}$ limitation showed that $g_{\text {cyt }}$ was higher in females than in males during salt stress under both types of $\mathrm{N}$ supplies (Figure 6). The proportion of $g_{\text {cyt }}$ in the $\mathrm{CO}_{2}$ diffusion conductance increases along with a reduced contact between 
614

615

616

617

618

619

620

621

622

623

624

625

626

627

628

629

630

631

632

633

634

635

chloroplasts and cell surfaces (Lu et al. 2016). Modifications in the chloroplast shape and structure affect the distance of cytosolic $\mathrm{CO}_{2}$ diffusion under abiotic stress (Shu et al. 2012). Changes in the shape of female chloroplasts caused by salt stress probably decreased the $g_{\text {cyt }}$ value and, thus. $g_{\mathrm{m}}$ as well.

Generally, the distance has little effect on $\mathrm{CO}_{2}$ diffusion when the cellular stromal distance between the plasma membrane and chloroplast envelope is relatively short. However, intracellular CA could convert $\mathrm{CO}_{2}$ into $\mathrm{HCO}_{3}{ }^{-}$, having the highest activity in the stroma and, thus, affecting $g_{\mathrm{m}}$ (Evans et al. 2009). The effects of $\mathrm{N}$ forms on $g_{\mathrm{st}}$ and $g_{\text {cyt }}$ were sex-dependent under salt stress. $\mathrm{NH}_{4}{ }^{+}$-fed females had greater $g_{\text {cytl }}$ but lower $g_{\mathrm{cw}}$ and $g_{\mathrm{st} 1}$ than those under $\mathrm{NO}_{3}{ }^{-}$supply, while males had higher $g_{\mathrm{cw}}$ and lower $g_{\mathrm{st} 2}$ under $\mathrm{NH}_{4}{ }^{+}$than under $\mathrm{NO}_{3}{ }^{-}$supply (Figures 6, 8; Figure S2). Additionally, nitrogen availability and forms have been found to affect CA activities under salt stress (Siddiqui et al. 2010, Nawaz et al. 2020). Therefore, CA may increase its effect on $g_{\mathrm{m}}$ inside chloroplasts. In addition, increasing evidence suggests that aquaporins are capable of transporting $\mathrm{CO}_{2}$ in plants and the aquaporin activity is associated with $g_{\mathrm{m}}$ in leaves (Maurel et al. 2008, Heckwolf et al. 2011). Some studies have suggested that salt stress or nitrogen availability increase aquaporin activities (Qi et al. 2009), which indicates that the variation in aquaporin activities under salt stress and $\mathrm{N}$ availability might partially affect $g_{\mathrm{m}}$.

The effects of $\mathrm{N}$ forms on $g_{\mathrm{m}}$ and $A$ largely depend on salt stress tolerance and the 
636

637

energy allocation of plants. $\mathrm{N}$ forms affect matter distribution and carbohydrate consumption in plants (Guo et al. 2007, Ashraf et al. 2018). A greater investment in the leaf area and cell wall thickness results in a lower allocation of resources to leaf photosynthesis in females. Net photosynthesis could be reduced not only by a greater energy investment in structures but also by higher maintenance costs, including the effects of abiotic stresses (Guo et al. 2007). Females show a higher respiration rate than males under drought stress in Populus cathayana (Han et al. 2013). The higher dark respiration rate in $P$. cathayana females under salt stress found in the present study was probably associated with the leaf photosynthesis (Table S2). $\mathrm{NO}_{3}{ }^{-}$ assimilation in plants requires more energy than $\mathrm{NH}_{4}^{+}$assimilation, while carbon losses through leaf and root respiration are higher under $\mathrm{NH}_{4}{ }^{+}$than under $\mathrm{NO}_{3}{ }^{-}$supply. Whether or how $\mathrm{N}$ assimilation in plants affects photosynthesis under salt stress was not clear. In the future, it will be important to clarify the sexually different leaf photosynthesis under salt stress with different $\mathrm{N}$ form supplies based on the relationship between photosynthesis and respiration consumption.

Importantly, the sex- and $\mathrm{N}$ form-specific investment in the root system architecture largely reflects energy requirements for foliage construction, thereby, affecting $g_{\mathrm{m}}$ and photosynthesis. In this study, the biomass allocation did not directly explain leaf $A$, whereas the biomass allocation had indirect effects on leaf $A$ through leaf structural traits (Figure 7). $\mathrm{NH}_{4}{ }^{+}$-fed males with a higher root biomass had high root construction costs, while $\mathrm{NO}_{3}{ }^{-}$-fed males with a higher leaf biomass had high energy 
658

659

660

661

662

663

664

665

666

667

668

669

670

671

672

673

674

675

676

677

678

679

cost from $\mathrm{NO}_{3}{ }^{-}$assimilation without salt stress. Such energy trade-offs between biomass and $A$ in males led to similar $g_{\mathrm{m}}$ and photosynthesis under both $\mathrm{N}$ forms. Females produce thinner roots than males and they intensively facilitate the exploration of thesurrounding soil and $\mathrm{Na}^{+}$uptake (Xia et al. 2020). Certainly, the larger root system and ion uptake enhanced the energy consumption of females exposed to salt stress, especially under $\mathrm{NH}_{4}{ }^{+}$supply.

\section{Conclusions}

This study suggested that leaf $g_{\mathrm{m}}$ relative to $g_{\mathrm{s}}$ under salt stress was the main restraint on leaf $A$ under $\mathrm{NO}_{3}{ }^{-}$and $\mathrm{NH}_{4}{ }^{+}$supplies. Among leaf structural components, $S_{\mathrm{c}} / S$ and $S / W$ were critical factors affecting $g_{\mathrm{m}}$ and $A$ (Figure 7). Salt stress increased $S / W$, and reduced intercellular air space and $S_{\mathrm{c}} / S$, resulting in an increased length of cytoplasmic and stromal paths, and inhibition of $g_{\mathrm{m}}$ and $A$ in females (Figure 8). Conversely, males had a better tradeoff between leaf structure and photosynthesis (more chloroplasts and fewer spongy cells), and they have a good ability to regulate leaf $\mathrm{CO}_{2}$ diffusion and light capture into the leaf, thereby alleviating $g_{\mathrm{m}}$ and $A$ decreases under salt stress and both $\mathrm{N}$ forms (Figure 8). The low $\mathrm{CO}_{2}$ diffusion conductance in $\mathrm{NH}_{4}{ }^{+}$-fed females was mainly due to $g_{\text {st1 }}$ and $g_{\text {cw }}$, while $\mathrm{NO}_{3}{ }^{-}$-fed males had a higher cytoplasm conductance (Figure 8). Moreover, biomass allocation in both sexes indirectly affected leaf structural traits and $A$ under both $\mathrm{N}$ forms. This study will not only help us to predict potential climate change impacts on dioecious $P$. 
680

681

682

683

684

685

686

687

688

689

690

691

692

693

694 Conflict of interest The authors declare that they have no conflict of interest.

cathayana populations, but also to predict the photosynthetic behavior of tree species with different $\mathrm{N}$-source preferences and spatiotemporal changes in $\mathrm{N}$ assimilation at rising atmospheric $\mathrm{CO}_{2}$.

Acknowledgements This work was supported by the Natural Science Foundation of China (31800507) and the Talent Program of the Hangzhou Normal University (2016QDL020).

Author contributions Miao Liu had the main responsibility for data collection, analysis and writing, Xiucheng Liu and Xuhua Du contributed to data analysis, Helena Korpelainen and Ülo Niinemets contributed to the interpretation of data and manuscript preparation, and Chunyang Li (the corresponding author) had the overall responsibility for the experimental design and project management. 
695

696

697

698

699

700

701

702

703

704

705

706

707

708

709

710

711

712

713

714

715

716

\section{References}

Ashraf M, Shahzad SM, Imtiaz M, Rizwan MS, Arif MS, Kausar R (2018) Nitrogen nutrition and adaptation of glycophytes to saline environment: a review. Arch Agron Soil Sci 64:1181-1206.

Berghuijs HN, Yin X, Ho QT, Driever SM, Retta MA, Nicolaï BM, Struik PC (2016) Mesophyll conductance and reaction-diffusion models for $\mathrm{CO}_{2}$ transport in $\mathrm{C}_{3}$ leaves; needs, opportunities and challenges. Plant Sci 252:62-75.

Bernacchi CJ, Singsaas EL, Pimentel C, Portis Jr AR, Long SP (2001) Improved temperature response functions for models of Rubisco-limited photosynthesis. Plant Cell Environ 24:253-259.

Bernacchi CJ, Portis AR, Nakano H, Von Caemmerer S, Long SP (2002) Temperature response of mesophyll conductance. Implications for the determination of Rubisco enzyme kinetics and for limitations to photosynthesis in vivo. Plant Physiol 130:1992-1998.

Bi J, Liu X, Liu S, Wang Y, Liu M (2020) Microstructural and physiological responses to cadmium stress under different nitrogen forms in two contrasting Populus clones. Environ Exp Bot 169:103897.

Brooks A, Farquhar GD (1985) Effect of temperature on the $\mathrm{CO}_{2} / \mathrm{O}_{2}$ specificity of ribulose-1, 5-bisphosphate carboxylase/oxygenase and the rate of respiration in the light. Planta 165:397-406.

Cano FJ, Sánchez-Gómez D, Rodríguez - Calcerrada J, Warren CR, Gil L, Aranda I (2013) Effects of drought on mesophyll conductance and photosynthetic 
Chen J, Duan B, Xu G, Korpelainen H, Niinemets Ü, Li C (2016) Sexual competition Physiol 36:1353-1368. affects biomass partitioning, carbon-nutrient balance, $\mathrm{Cd}$ allocation and ultrastructure of Populus cathayana females and males exposed to Cd stress. Tree

Chen L, Han Y, Jiang H, Korpelainen H, Li C (2011) Nitrogen nutrient status induces sexual differences in responses to cadmium in Populus yunnanensis. J Exp Bot 62:5037-5050.

Chen TW, Kahlen K, Stützel H (2015) Disentangling the contributions of osmotic and ionic effects of salinity on stomatal, mesophyll, biochemical and light limitations to photosynthesis. Plant Cell Environ 38:1528-1542.

Ethier GJ, Livingston NJ (2004) On the need to incorporate sensitivity to $\mathrm{CO}_{2}$ transfer conductance into the Farquhar-von Caemmerer-Berry leaf photosynthesis model. Plant Cell Environ 27:137-153.

Evans JR, Kaldenhoff R, Genty B, Terashima I (2009) Resistances along the $\mathrm{CO}_{2}$ diffusion pathway inside leaves. J Exp Bot 60:2235-2248.

Farquhar GD, von Caemmerer SV, Berry JA (1980) A biochemical model of photosynthetic $\mathrm{CO}_{2}$ assimilation in leaves of $\mathrm{C}_{3}$ species. Planta 149:78-90.

Flexas J, Díaz-Espejo A, Conesa MA, Coopman R, Douthe C, Gago J, Gallé A, Galmés J, Medrano H, Ribas-Carbo M, Tomàs M, Niinemets Ü (2016) Mesophyll conductance to $\mathrm{CO}_{2}$ and Rubisco as targets for improving intrinsic water use efficiency in $\mathrm{C}_{3}$ plants. Plant Cell Environ 39:965-982. 
Flexas J, Ribas-Carbo MI, Diaz-Espejo AN, GalmES J, Medrano H (2008) Mesophyll conductance to $\mathrm{CO}_{2}$ : current knowledge and future prospects. Plant Cell Environ 31:602-621.

Genty B, Briantais JM, Baker NR (1989) The relationship between the quantum yield of photosynthetic electron transport and quenching of chlorophyll fluorescence. BBA-Gen Subjects 990:87-92.

Golldack D, Li C, Mohan H, Probst N (2014) Tolerance to drought and salt stress in plants: unraveling the signaling networks. Front Plant Sci 5:151.

Grassi G, Magnani F (2005) Stomatal, mesophyll conductance and biochemical limitations to photosynthesis as affected by drought and leaf ontogeny in ash and oak trees. Plant Cell Environ 28:834-849.

Guo S, Zhou Y, Shen Q, Zhang F (2007) Effect of ammonium and nitrate nutrition on some physiological processes in higher plants-growth, photosynthesis, photorespiration, and water relations. Plant Biol 9:21-29.

Han Y, Wang Y, Jiang H, Wang M, Korpelainen H, Li C (2013) Reciprocal grafting separates the roles of the root and shoot in sex-related drought responses in Populus cathayana males and females. Plant Cell Environ 36:356-364.

Harley PC, Thomas RB, Reynolds JF, Strain BR (1992) Modelling photosynthesis of cotton grown in elevated $\mathrm{CO}_{2}$. Plant Cell Environ 15:271-282.

Heckwolf M, Pater D, Hanson DT, Kaldenhoff R (2011) The Arabidopsis thaliana aquaporin AtPIP1; 2 is a physiologically relevant $\mathrm{CO}_{2}$ transport facilitator. Plant $\mathrm{J}$ $67: 795-804$. 
Henry DA, Simpson RJ, Macmillan RH (2000) Seasonal changes and the effect of temperature and leaf moisture content on intrinsic shear strength of leaves of pasture grasses. Aust J Agr Res 51:823-831.

Hu W, Lu Z, Meng F, Li X, Cong R, Ren T, Sharkey TD, Lu J (2020) The reduction in leaf area precedes that in photosynthesis under potassium deficiency: the importance of leaf anatomy. New Phytol. https://doi.org/10.1111/nph.16644.

John GP, Scoffoni C, Buckley TN, Villar R, Poorter H, Sack L (2017) The anatomical and compositional basis of leaf mass per area. Ecol Lett 20:412-425.

Liu M, Bi J, Liu X, Kang J, Korpelainen H, Niinemets Ü, Li C (2020a) Microstructural and physiological responses to cadmium stress under different nitrogen levels in Populus cathayana females and males. Tree Physiol 40:30-45.

Liu M, Liu X, Kang J, Korpelainen H, Li C (2020b) Are males and females of Populus cathayana differentially sensitive to Cd stress? J Hazard Mater 393:122411.

Liu M, Wang Y, Liu X, Korpelainen H, Li C (2021) Intra-and intersexual interactions shape microbial community dynamics in the rhizosphere of Populus cathayana females and males exposed to excess Zn. J Hazard Mater 402:123783.

Lu Z, Lu J, Pan Y, Lu P, Li X, Cong R, Ren T (2016) Anatomical variation of mesophyll conductance under potassium deficiency has a vital role in determining leaf photosynthesis. Plant Cell Environ 39:2428-2439.

Martins SC, Galmes J, Cavatte PC, Pereira LF, Ventrella MC, Damatta FM (2014) Understanding the low photosynthetic rates of sun and shade coffee leaves: 
bridging the gap on the relative roles of hydraulic, diffusive and biochemical constraints to photosynthesis. Plos One 9:e95571.

Maurel C, Verdoucq L, Luu DT, Santoni V (2008) Plant aquaporins: membrane channels with multiple integrated functions. Annu Rev Plant Biol 59:595-624.

787

Nawaz F, Shehzad MA, Majeed S, Ahmad KS, Aqib M, Usmani MM, Shabbir RN

788 (2020) Role of mineral nutrition in improving drought and salinity tolerance in field crops. Agronomic Crops 129-147.

Niinemets U (2007) Photosynthesis and resource distribution through plant canopies. Plant Cell Environ 30:1052-1071.

Niinemets Ü (1999) Research review. Components of leaf dry mass per areaphysiological variation. J Exp Bot 60:2433-2449. 
Nobel PS (1991) Physicochemical and environmental plant physiology, 4th edn. San Diego, CA: Academic Press.

Onoda Y, Wright IJ, Evans JR, Hikosaka K, Kitajima K, Niinemets Ü, Poorter H, Tosens T, Westoby M (2017) Physiological and structural tradeoffs underlying the leaf economics spectrum. New Phytol 214:1447-1463.

Ort DR, Merchant SS, Alric J, Barkan A, Blankenship RE, Bock R, Moore TA (2015) Redesigning photosynthesis to sustainably meet global food and bioenergy demand. P Natl Acad Sci USA 112:8529-8536.

Peguero-Pina JJ, Sisó S, Flexas J, Galmés J, García-Nogales A, Niinemets Ü, Sancho-Knapik D, Saz MÁ, Gil-Pelegrín E (2017) Cell -level anatomical characteristics explain high mesophyll conductance and photosynthetic capacity in sclerophyllous Mediterranean oaks. New Phytol 214:585-596.

Pérez-López U, Robredo A, Lacuesta M, Mena-Petite A, Munoz-Rueda A (2012) Elevated $\mathrm{CO}_{2}$ reduces stomatal and metabolic limitations on photosynthesis caused by salinity in Hordeum vulgare. Photosynth Res 111:269-283.

Pinheiro C, Chaves MM (2011) Photosynthesis and drought: can we make metabolic connections from available data? J Exp Bot 62:869-882.

Praxedes SC, De Lacerda CF, DaMatta FM, Prisco JT, Gomes-Filho E (2010) Salt tolerance is associated with differences in ion accumulation, biomass allocation and photosynthesis in cowpea cultivars. J Agron Crop Sci 196:193-204.

Qi CH, Chen M, Song J, Wang BS (2009) Increase in aquaporin activity is involved in leaf succulence of the euhalophyte Suaeda salsa, under salinity. Plant Sci 
828

Qiu R, Katul GG (2020) Maximizing leaf carbon gain in varying saline conditions: An optimization model with dynamic mesophyll conductance. Plant J 101:543-554.

Ren T, Weraduwage SM, Sharkey TD (2019) Prospects for enhancing leaf photosynthetic capacity by manipulating mesophyll cell morphology. J Exp Bot 70:1153-1165.

Rondeau-Mouro C, Defer D, Leboeuf E, Lahaye M (2008) Assessment of cell wall porosity in Arabidopsis thaliana by NMR spectroscopy. Inter J Biol Macromol 42:83-92.

Rosseel Y (2012) Lavaan: An R package for structural equation modeling and more. Version 0.5-12 (BETA). J Stat Softw 48:1-36.

Siddiqui MH, Mohammad F, Khan MN, Al-Whaibi MH, Bahkali AH (2010) Nitrogen in relation to photosynthetic capacity and accumulation of osmoprotectant and nutrients in Brassica genotypes grown under salt stress. Agr Sci China 9:671-680.

Scoffoni C, Sack L, Ort D (2017) The causes and consequences of leaf hydraulic decline with dehydration. J Exp Bot 68:4479-4496.

Shu S, Yuan LY, Guo SR, Sun J, Liu CJ (2012) Effects of exogenous spermidine on photosynthesis, xanthophyll cycle and endogenous polyamines in cucumber seedlings exposed to salinity. Afr J Biotechnol 11:6064-6674.

Tavakkoli E, Fatehi F, Coventry S, Rengasamy P, McDonald GK (2011) Additive effects of $\mathrm{Na}^{+}$and $\mathrm{Cl}^{-}$ions on barley growth under salinity stress. J Exp Bot 62:2189-2203. 
Terashima I, Hanba YT, Tholen D, Niinemets Ü (2011) Leaf functional anatomy in relation to photosynthesis. Plant Physiol 155:108-116.

Thain JF (1983) Curvature correlation factors in the measurements of cell surface areas in plant tissues. J Exp Bot 34:87-94.

Tomás M, Flexas J, Copolovici L, Galmés J, Hallik L, Medrano H, Niinemets Ü (2013) Importance of leaf anatomy in determining mesophyll diffusion conductance to $\mathrm{CO}_{2}$ across species: quantitative limitations and scaling up by models. J Exp Bot 64:2269-2281.

Tosens T, Nishida K, Gago J, Coopman RE, Cabrera HM, Carriquí M, Talts E (2016) The photosynthetic capacity in 35 ferns and fern allies: mesophyll $\mathrm{CO}_{2}$ diffusion as a key trait. New Phytol 209:1576-1590.

Tosens T, Niinemets Ü, Vislap V, Eichelmann H, Castro-Diez P (2012a) Developmental changes in mesophyll diffusion conductance and photosynthetic capacity under different light and water availabilities in Populus tremula: how structure constrains function. Plant Cell Environ 35:839-856.

Tosens T, Niinemets Ü, Westoby M, Wright IJ (2012b) Anatomical basis of variation in mesophyll resistance in eastern Australian sclerophylls: news of a long and winding path. J Exp Bot 63:5105-5119.

Veromann-Jürgenson L-L, Tosens T, Brodribb TJ, Niinemets Ü (2020) Pivotal role of mesophyll conductance in shaping photosynthetic performance across 67 structurally diverse gymnosperm species. Inter J Plant Sci 181:116-128.

Wankhade SD, Cornejo MJ, Mateu-Andrés I, Sanz A (2013) Morpho-physiological 
variations in response to $\mathrm{NaCl}$ stress during vegetative and reproductive development of rice. Acta Physiol Plant 35:323-333.

873 Wang X, Du T, Huang J, Peng S, Xiong D (2018) Leaf hydraulic vulnerability triggers 874 the decline in stomatal and mesophyll conductance during drought in rice. J Exp Bot 69:4033-4045.

876

Williams K, Percival F, Merino J, Mooney HA (1987) Estimation of tissue construction cost from heat of combustion and organic nitrogen content. Plant Cell Environ 10:725-734.

Xia ZC, He Y, Yu L, Lv RB, Korpelainen H, Li CY (2020) Sex-specific strategies of phosphorus acquisition in Populus cathayana as affected by soil $\mathrm{P}$ availability and distribution. New Phytol 225:782-792.

Yin X, Struik PC, Romero P, Harbinson J, Evers JB, Van Der Putten PE, Vos JAN (2009) Using combined measurements of gas exchange and chlorophyll fluorescence to estimate parameters of a biochemical $\mathrm{C}_{3}$ photosynthesis model: a critical appraisal and a new integrated approach applied to leaves in a wheat (Triticum aestivum) canopy. Plant Cell Environ 32:448-464.

Zait Y, Shtein I, Schwartz A (2019) Long-term acclimation to drought, salinity and temperature in the thermophilic tree Ziziphus spina-christi: revealing different tradeoffs between mesophyll and stomatal conductance. Tree Physiol 39:701-716.

Zhu XG, Long SP, Ort DR (2010) Improving photosynthetic efficiency for greater yield. Annu Rev Plant Biol 61:235-261. 
893

894

895

896

897

898

899

900

901

902

903

904

905

906

907

908

909

910

911 intercellular air space $\left(S_{\mathrm{m}} / S\right)($ b), the chloroplast surface area exposed to intercellular

912 air space per leaf area $\left(S_{\mathrm{c}} / S\right)(\mathrm{c})$ and the cell wall thickness $\left(T_{\mathrm{cw}}\right)(\mathrm{d})$ in $P$. cathayana

913 females (F) and males (M) grown with $\mathrm{NO}_{3}{ }^{-}$or $\mathrm{NH}_{4}{ }^{+}$supply, and with or without salt

Figure legends

Figure 1 Representative light microscopy images $(a, b)$ and transmission electron microscopy images $(\mathrm{c}, \mathrm{d})$ of the leaves of $P$. cathayana females and males grown with $\mathrm{NO}_{3}{ }^{-}$or $\mathrm{NH}_{4}{ }^{+}$supply, and with or without salt stress $(50 \mathrm{mM} \mathrm{NaCl}$ addition for 14 days). Bar $=50 \mu \mathrm{m}$ for images a and $\mathrm{b}$. Leaf upper epidermis (ue), leaf mesophyll palisade tissue (pl), leaf mesophyll spongy tissue (sp), leaf lower epidermis (le), leaf vascular tissue (v), cell wall (cw), chloroplast (ch) and starch granule (s).

Figure 2 Relationships of the light-saturated rate of photosynthesis with stomatal conductance $\left(g_{\mathrm{s}}\right)$ (a) and mesophyll conductance $\left(g_{\mathrm{m}}\right)(\mathrm{b})$, and the relationships of $g_{\mathrm{m}}$ with leaf $\mathrm{Na}^{+}$concentration (c) and $\mathrm{CO}_{2}$ drawdown $\left(C_{\mathrm{i}}-C_{\mathrm{c}}\right)(\mathrm{d})$ from sub-stomatal cavities $\left(C_{\mathrm{i}}\right)$ to chloroplasts $\left(C_{\mathrm{c}}\right)$ in $P$. cathayana females $(\mathrm{F})$ and males $(\mathrm{M})$ grown with $\mathrm{NO}_{3}{ }^{-}$or $\mathrm{NH}_{4}{ }^{+}$supply, and with or without salt stress. Salt stress application as in Figure 1.

Figure 3 Relationships of $\mathrm{CO}_{2}$ mesophyll conductance $\left(g_{\mathrm{m}}\right)$ with the volume fraction of intercellular air space $\left(f_{\text {ias }}\right)(a)$, the surface area of mesophyll cells adjacent to stress. Salt stress application as in Figure 1. 
916 Figure 4 Quantitative photosynthetic limitations in leaves of $P$. cathayana females (F)

917 and males (M) grown with $\mathrm{NO}_{3}{ }^{-}$or $\mathrm{NH}_{4}{ }^{+}$supply, and with or without salt stress. The

918 photosynthetic limitation $\mathrm{d} A / A=S_{\mathrm{L}}+M C_{\mathrm{L}}+B_{\mathrm{L}}$. $S_{\mathrm{L}}$, stomatal limitation; $M C_{\mathrm{L}}$,

919 mesophyll conductance; $B_{\mathrm{L}}$, biochemical limitation. Salt stress application as in 920 Figure 1.

922 Figure 5 The share of limitations of $g_{m}$ among gas-phase (a) and liquid-phase (b)

923 pathways, and absolute values of gas- (c) and liquid-phase (d) conductance in leaves 924 of $P$. cathayana females and males grown with $\mathrm{NO}_{3}{ }^{-}$or $\mathrm{NH}_{4}{ }^{+}$supply, and with or 925 without salt stress. Salt stress application as in Figure 1.

Figure 6 Anatomical limitations of $\mathrm{CO}_{2}$ mesophyll conductance $\left(g_{\mathrm{m}}\right)$ and $\mathrm{CO}_{2}$ conductance in leaves of $P$. cathayana females (F) and males (M) grown with $\mathrm{NO}_{3}{ }^{-}$or $\mathrm{NH}_{4}{ }^{+}$supply with or without salt stress. The share of $\mathrm{CO}_{2}$ liquid-phase diffusive limitation $(\mathrm{a}, \mathrm{b})$ and absolute values of conductance among cytoplasm $\left(g_{\text {cyt1 }}\right)$ and chloroplast stroma $\left(g_{\mathrm{st} 1}\right)$ (c), cell wall $\left(g_{\mathrm{cw}}\right)$, chloroplast envelope $\left(g_{\text {env }}\right)$ and plasma membrane $\left(g_{\mathrm{pl}}\right)(\mathrm{d})$. The $g_{\text {st } 1}$ variable is the stromal conductance perpendicular to cell 933 walls, and $g_{c y t 1}$ is the cytosolic conductance from the plasmalemma inner surface towards the outer surface of chloroplasts. A constant value of $0.0035 \mathrm{~m} \mathrm{~s}^{-1}$ was used for both plasmalemma and chloroplast envelope conductance. Additional components of the diffusion pathway are provided in Figure S2. Salt stress application as in Figure 
Figure 7 Direct and indirect effects of leaf structure, biomass allocation and the surface area of chloroplast exposed to intercellular air spaces per unit leaf area $\left(S_{\mathrm{c}} / S\right)$, mesophyll cell area per transverse section width $(S / W), \mathrm{CO}_{2}$ mesophyll conductance $\left(g_{\mathrm{m}}\right)$ and photosynthesis $(A)$ in $P$. cathayana females and males grown with $\mathrm{NO}_{3}{ }^{-}$or $\mathrm{NH}_{4}{ }^{+}$supply, and with or without salt stress. Multiple-layer rectangles represent the first component of PCA conducted for the leaf structure and biomass allocation. The arrows indicate the hypothesized direction of causation. The arrow width represents the strength of relationships. Black solid and dotted arrows represent positive and 947 negative relationships, respectively. Grey arrows represent nonsignificant 948 relationships. The leaf structure traits include mesophyll palisade cell area $\left(A_{\mathrm{pl}}\right)$, the 949 volume fraction of intercellular air space $\left(f_{\text {ias }}\right)$, leaf thickness $\left(T_{1}\right)$, mesophyll surface 950 area exposed to intercellular air space per unit leaf area $\left(S_{\mathrm{m}} / S\right)$, cell wall thickness $951\left(T_{\mathrm{cw}}\right)$, mesophyll length $\left(L_{\mathrm{m}}\right)$, mesophyll palisade tissue length $\left(L_{\mathrm{pl}}\right)$, mesophyll 952 spongy tissue length $\left(L_{\mathrm{sp}}\right)$, leaf dry mass per unit area $(L M A)$, mesophyll spongy cell 953 density $\left(D_{\mathrm{sp}}\right)$, chloroplast length $\left(L_{\mathrm{cl}}\right)$, mesophyll palisade cell density $\left(D_{\mathrm{pl}}\right)$, 954 chlorophyll content $(C h l)$, chloroplast width $\left(W_{\mathrm{cl}}\right)$, and mesophyll spongy cell area $955\left(A_{\mathrm{sp}}\right)$. The biomass allocation includes specific root length (SLR), root length density 956 (RLD), stem dry mass $\left(\mathrm{W}_{\mathrm{s}}\right)$, leaf dry mass $\left(\mathrm{W}_{\mathrm{l}}\right)$, root dry mass, shoot dry mass/root 957 dry mass $(\mathrm{S} / \mathrm{R})$, and leaf dry mass/(stem and root dry mass) $(\mathrm{L} /(\mathrm{S}+\mathrm{R}))$. The numbers 958 adjacent to the arrows are the standardized path coefficients. The significance values 

of $g_{\text {st2 }}$ under $\mathrm{NO}_{3}{ }^{-}$supply were higher in females than females. 
$982 \quad$ Figure 1
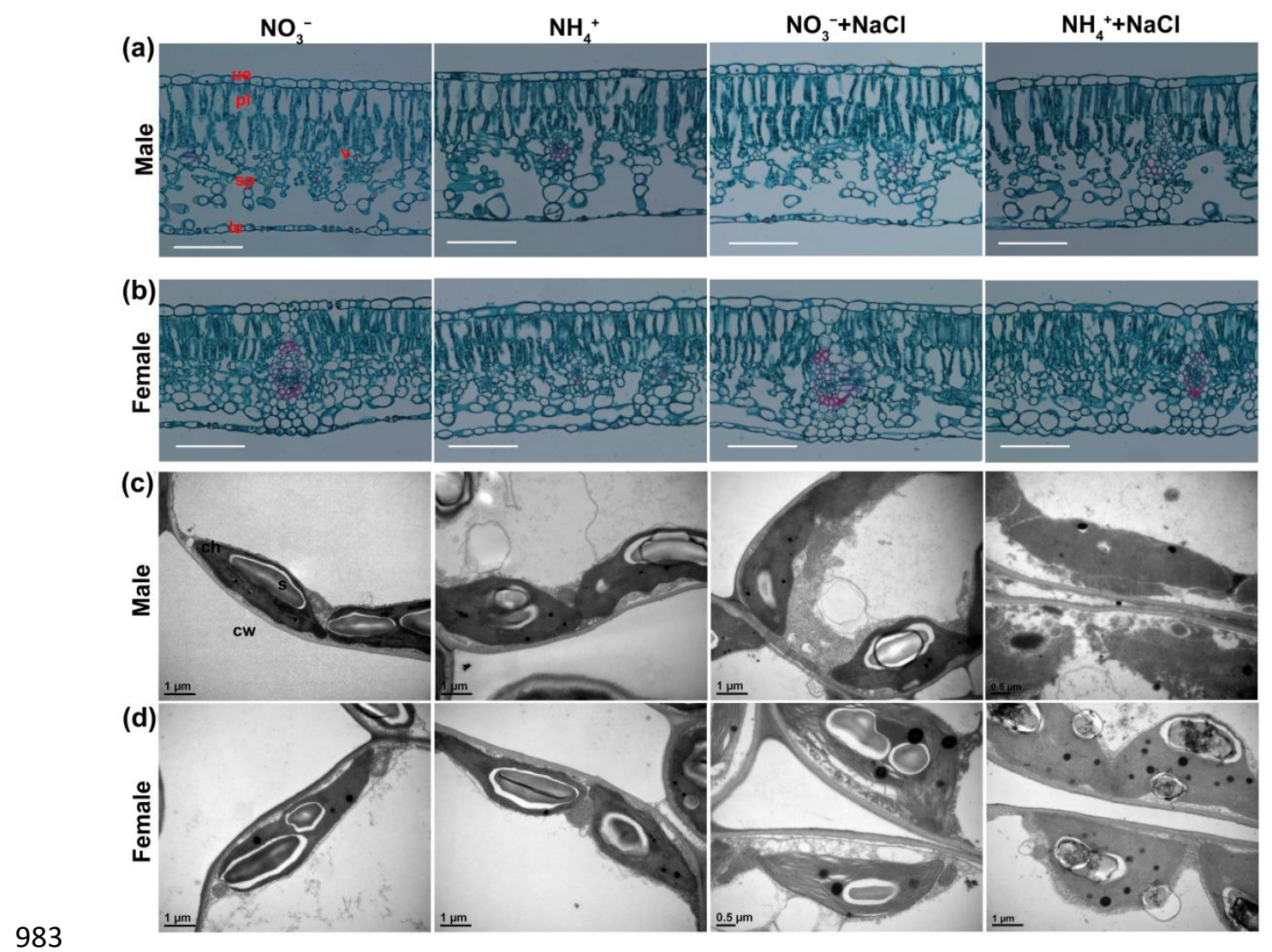
994

$995 \quad$ Figure 2
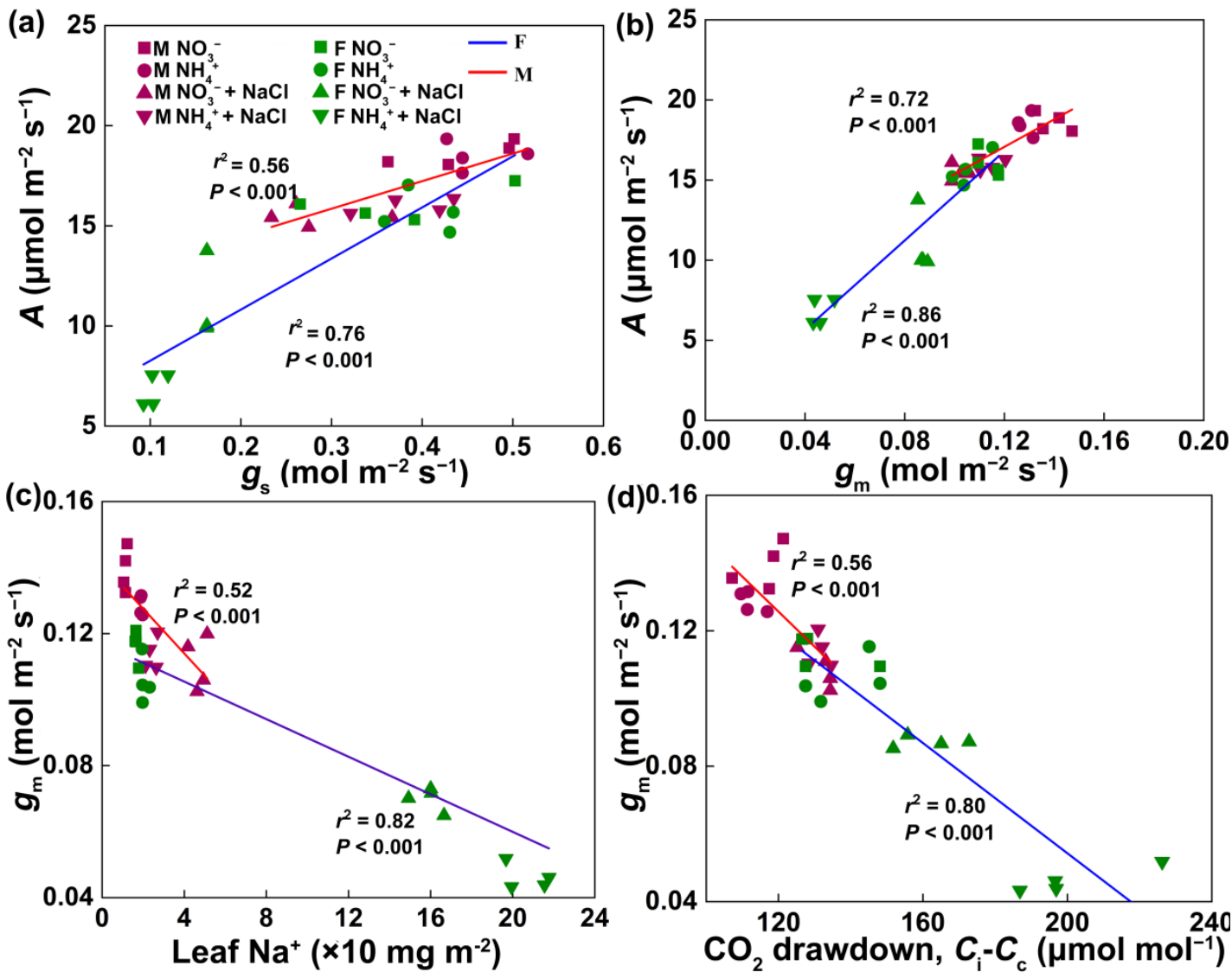

997

998

999

1000

1001

1002

1003

1004

1005

1006 
1008 Figure 3
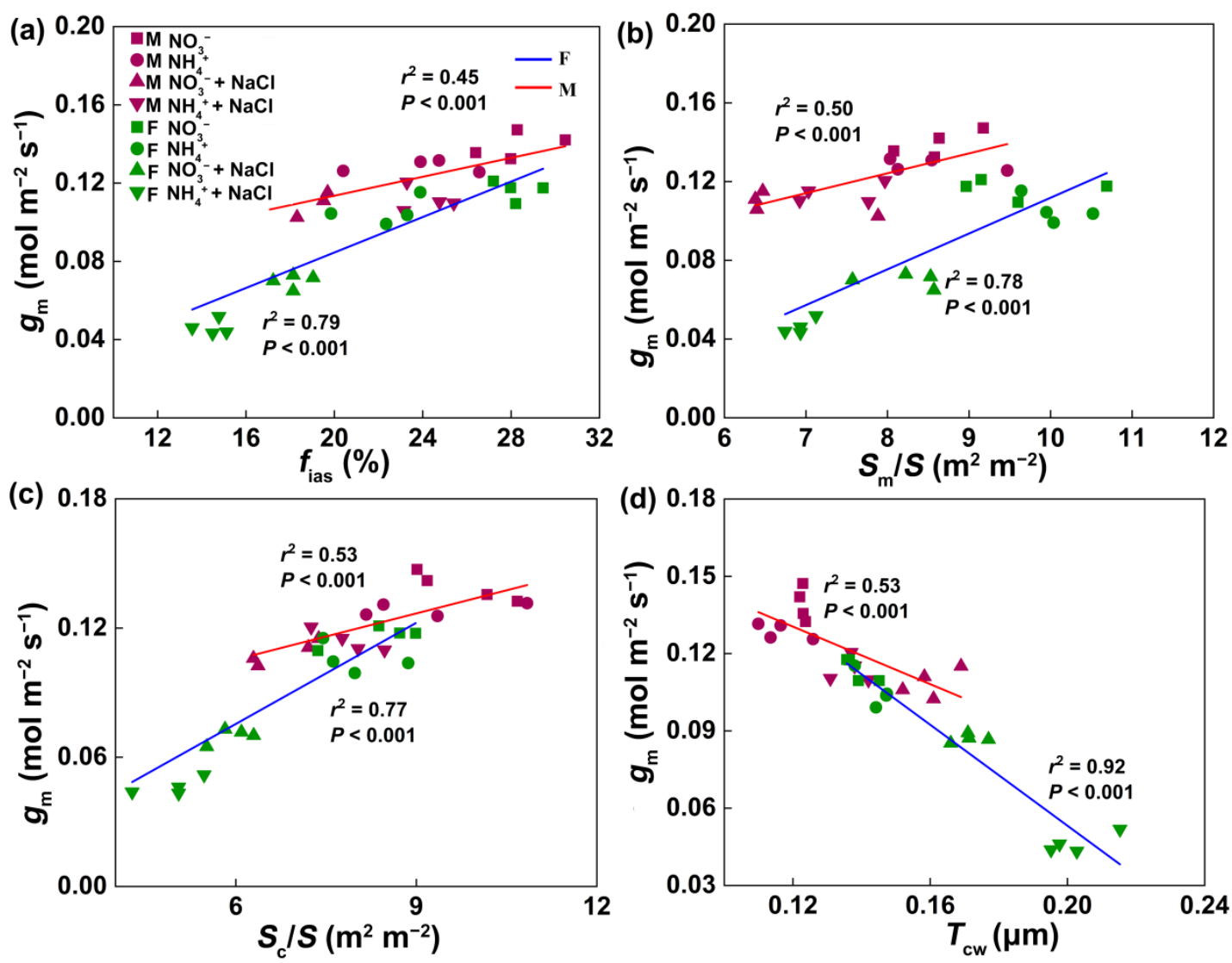

1010

1011

1012

1013

1014

1015

1016

1017

1018

1019 
$1021 \quad$ Figure 4

1022

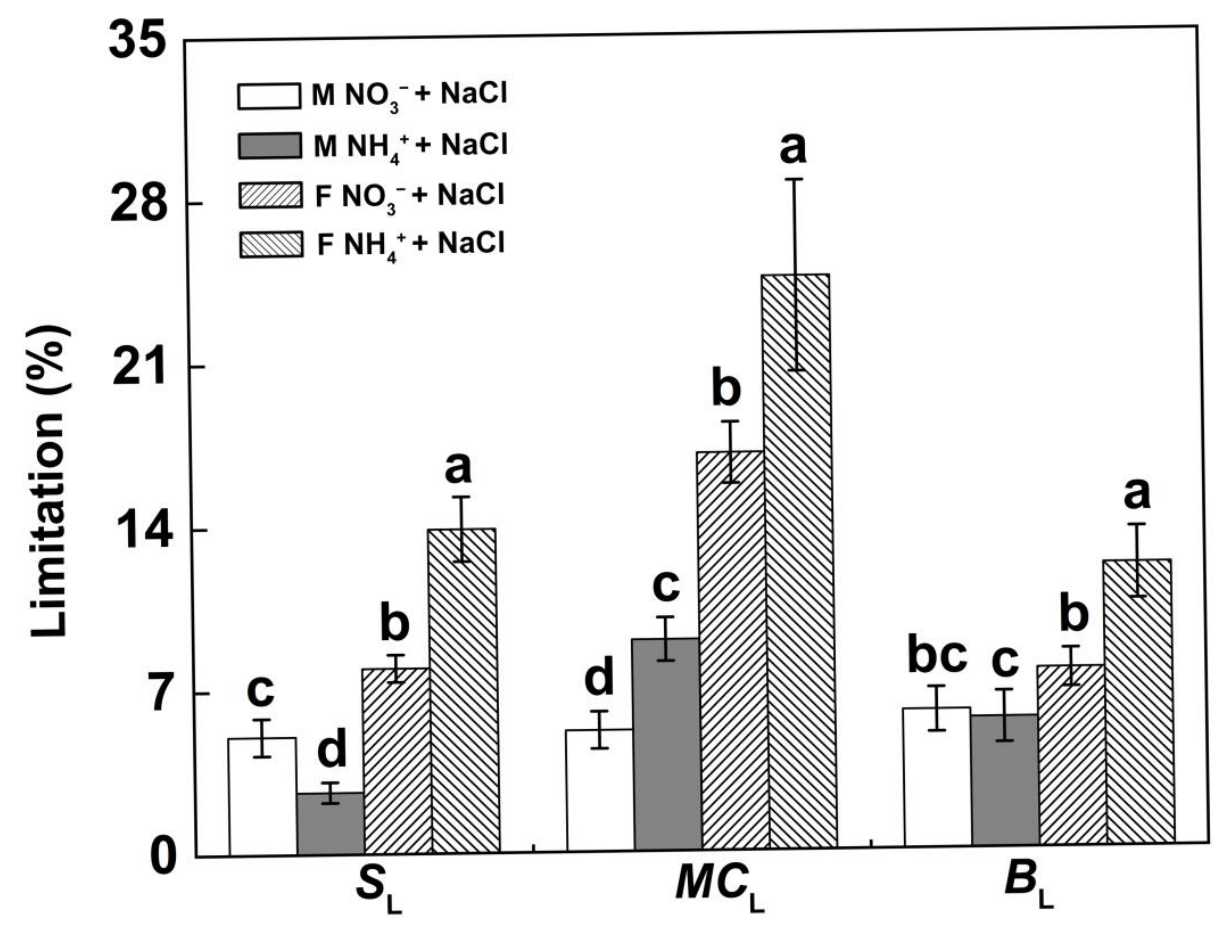

1023

1024

1025

1026

1027

1028

1029

1030

1031

1032

1033 
1035 Figure 5

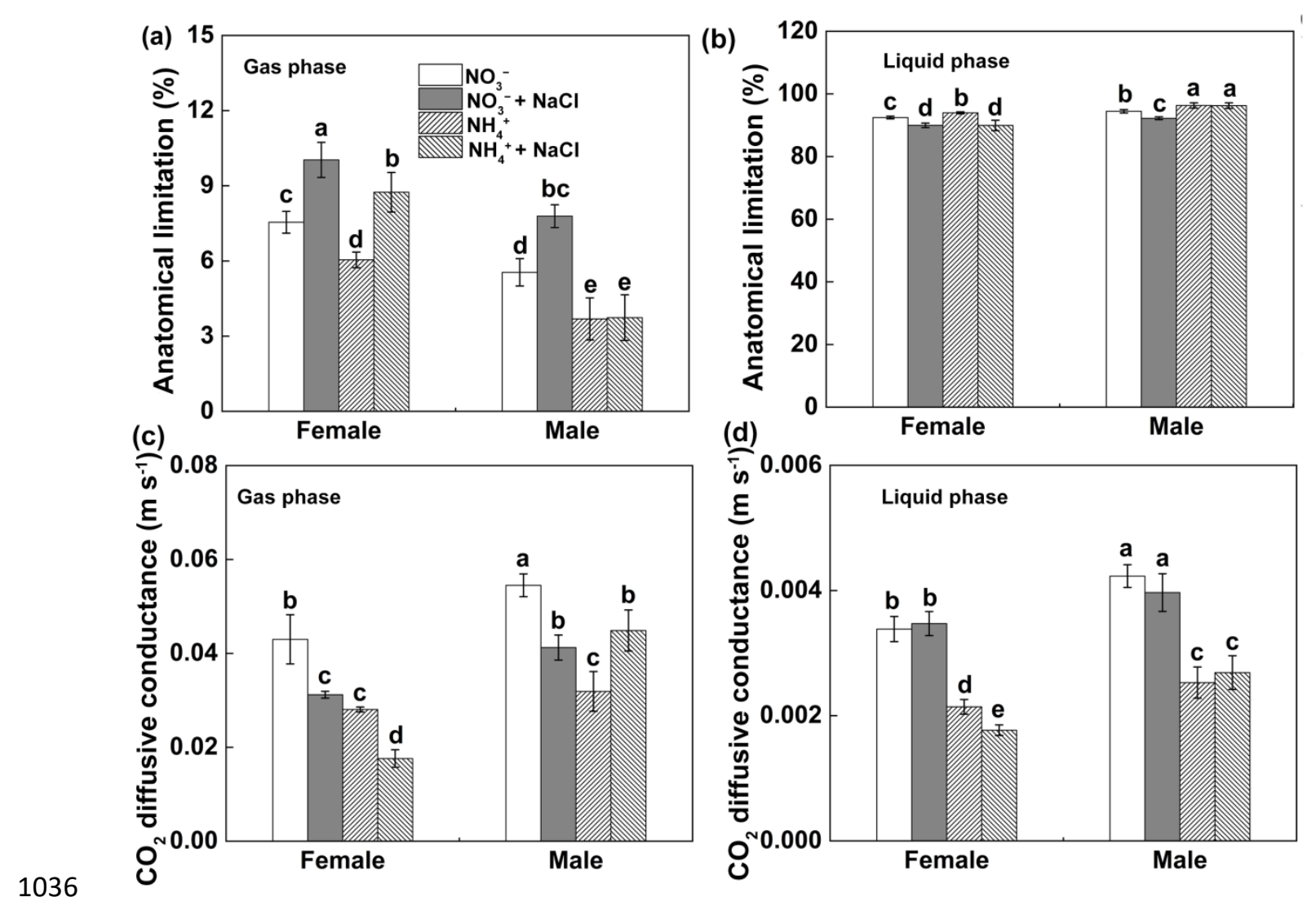



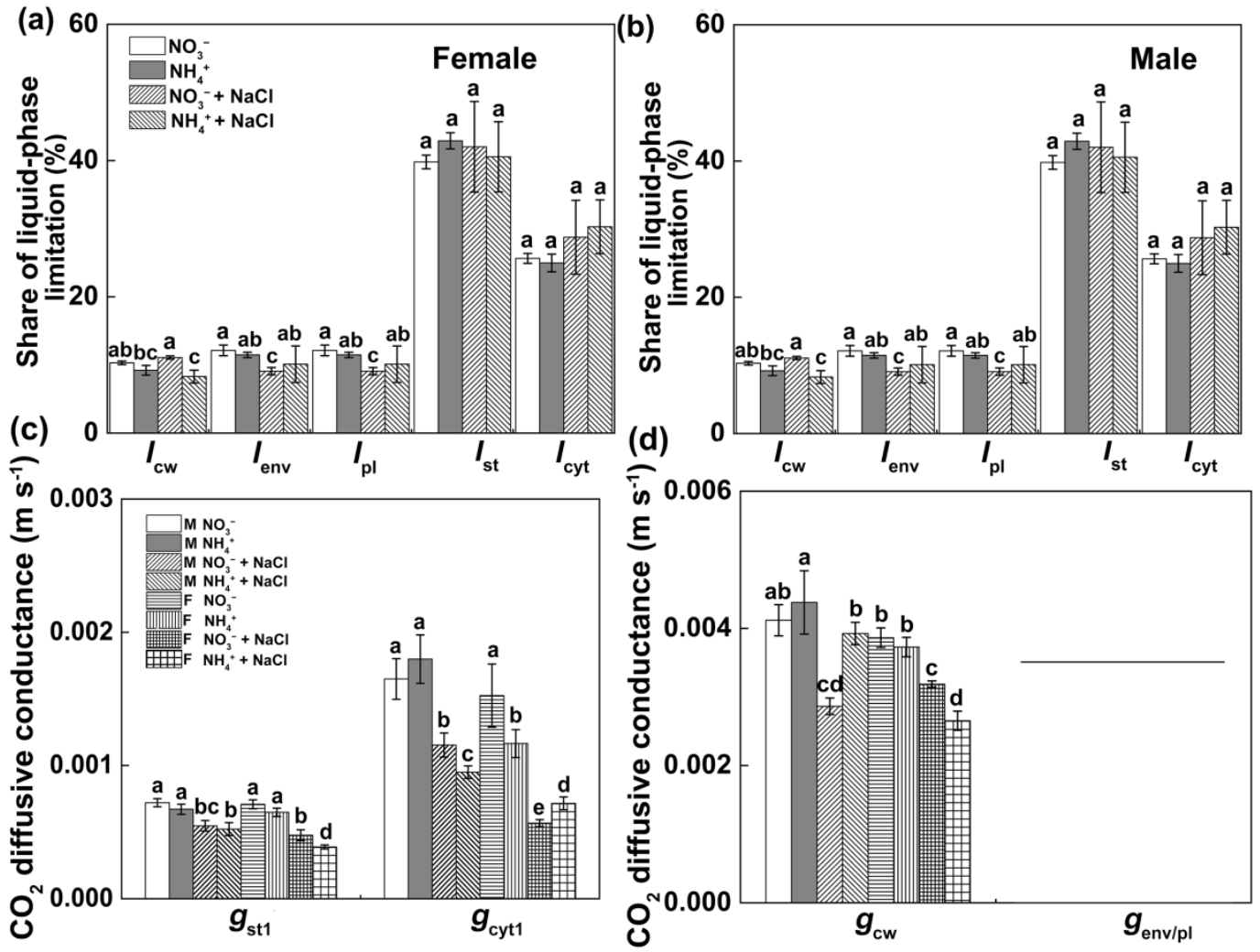

1039

1040

1041

1042

1043

1044

1045

1046

1047

1048

1049 


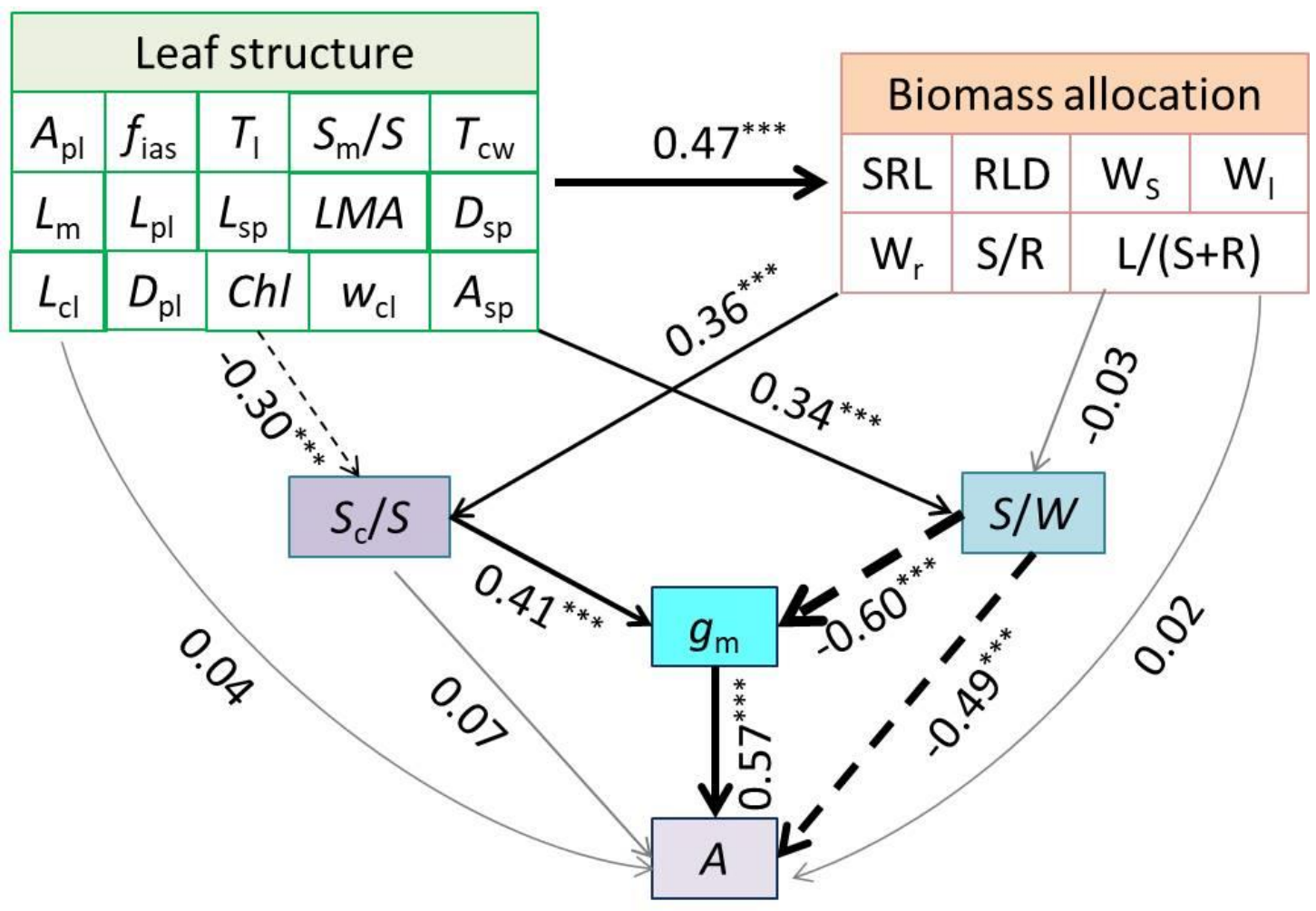

1052

1053

1054

1055

1056

1057

1058

1059

1060

1061 

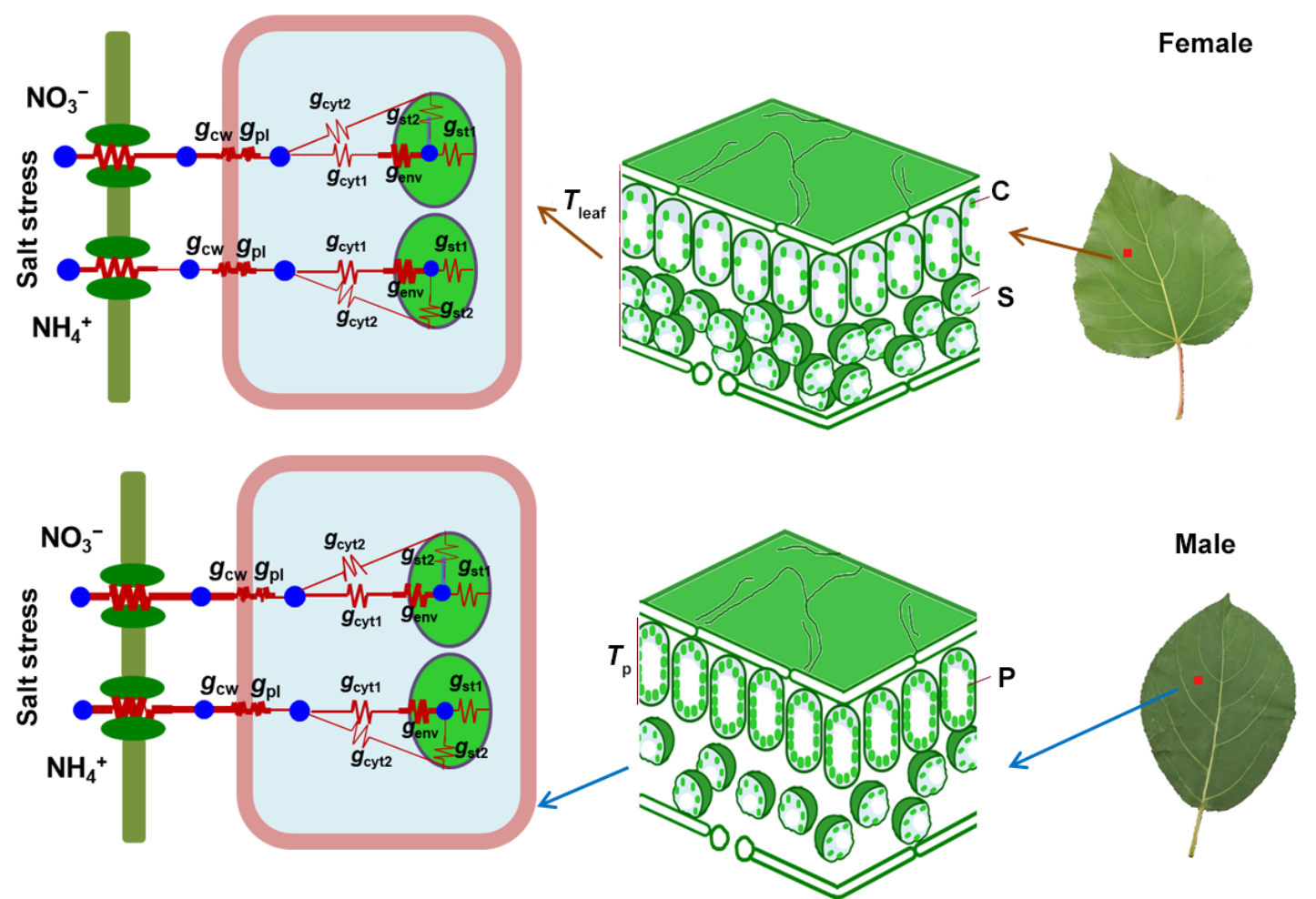
Table 1 Leaf biomass and area, leaf structural and gas exchange characteristics, leaf construction cost and root traits in $P$. cathayana females and males under $\mathrm{NO}_{3}{ }^{-}$or $\mathrm{NH}_{4}{ }^{+}$supply, and with or without salt stress.

\begin{tabular}{|c|c|c|c|c|c|c|c|c|c|c|c|c|}
\hline Salt & $\begin{array}{l}N \\
\text { form }\end{array}$ & Sex & $\begin{array}{l}\text { Leaf } \\
\text { biomass }\end{array}$ & Leaf area & $L M A$ & Leaf CC & $F_{\mathrm{v}} / F_{\mathrm{m}}$ & $J$ & $V_{\text {cmax }}$ & SRL & RLD & $\begin{array}{l}\text { Root } \\
\text { biomass }\end{array}$ \\
\hline 0 & $\mathrm{NO}_{3}{ }^{-}$ & Female & $14.14 \pm 0.93 \mathrm{a}$ & $85.14 \pm 5.90 \mathrm{a}$ & $37.83 \pm 3.57 \mathrm{~d}$ & $1.39 \pm 0.01 \mathrm{a}$ & $0.814 \pm 0.01 \mathrm{a}$ & $47.45 \pm 3.86 \mathrm{a}$ & $65.99 \pm 1.68 \mathrm{~b}$ & $6.91 \pm 0.50 \mathrm{~cd}$ & $1.70 \pm 0.15 \mathrm{a}$ & $8.04 \pm 0.44 \mathrm{a}$ \\
\hline 0 & $\mathrm{NO}_{3}{ }^{-}$ & Male & $8.69 \pm 0.28 \mathrm{~cd}$ & $51.65 \pm 6.57 \mathrm{~d}$ & $45.20 \pm 2.18 \mathrm{c}$ & $1.39 \pm 0.01 \mathrm{a}$ & $0.808 \pm 0.01 \mathrm{a}$ & $50.95 \pm 2.72 \mathrm{a}$ & $74.44 \pm 4.43 a$ & $7.27 \pm 1.08 \mathrm{~cd}$ & $0.671 \pm 0.06 \mathrm{e}$ & $4.08 \pm 0.35 \mathrm{~d}$ \\
\hline 0 & $\mathrm{NH}_{4}^{+}$ & Female & $12.83 \pm 1.46 \mathrm{~b}$ & $72.09 \pm 5.54 b$ & $36.62 \pm 2.78 \mathrm{~d}$ & $1.37 \pm 0.06 \mathrm{ab}$ & $0.815 \pm 0.01 \mathrm{a}$ & $35.18 \pm 3.85 b$ & $58.18 \pm 5.12 \mathrm{c}$ & $8.25 \pm 0.78 \mathrm{c}$ & $1.24 \pm 0.13 b$ & $6.87 \pm 0.44 \mathrm{~b}$ \\
\hline 0 & $\mathrm{NH}_{4}^{+}$ & Male & $8.41 \pm 0.74 \mathrm{~cd}$ & $43.77 \pm 1.20 \mathrm{~d}$ & $45.54 \pm 1.10 \mathrm{c}$ & $1.39 \pm 0.01 \mathrm{a}$ & $0.794 \pm 0.01 \mathrm{~b}$ & $47.78 \pm 0.99 \mathrm{a}$ & $66.17 \pm 3.44 \mathrm{~b}$ & $6.87 \pm 1.41 \mathrm{~cd}$ & $0.847 \pm 0.06 \mathrm{~d}$ & $5.38 \pm 0.25 \mathrm{c}$ \\
\hline 50 & $\mathrm{NO}_{3}^{-}$ & Female & $9.54 \pm 0.45 \mathrm{c}$ & $68.28 \pm 4.15 b c$ & $51.67 \pm 3.09 \mathrm{~b}$ & $1.37 \pm 0.004 \mathrm{ab}$ & $0.769 \pm 0.01 \mathrm{~cd}$ & $17.93 \pm 2.81 \mathrm{~d}$ & $51.47 \pm 4.09 \mathrm{~d}$ & $13.611 .15 \mathrm{a}$ & $1.29 \pm 0.05 \mathrm{~b}$ & $7.12 \pm 0.56 \mathrm{~b}$ \\
\hline 50 & $\mathrm{NO}_{3}{ }^{-}$ & Male & $8.06 \pm 0.60 \mathrm{de}$ & $50.60 \pm 5.96 \mathrm{~d}$ & $54.58 \pm 2.44 \mathrm{ab}$ & $1.39 \pm 0.01 \mathrm{a}$ & $0.773 \pm 0.01 \mathrm{c}$ & $35.13 \pm 3.90 \mathrm{~b}$ & $65.79 \pm 3.12 b$ & $6.51 \pm 0.67 \mathrm{~d}$ & $1.56 \pm 0.10 \mathrm{a}$ & $4.54 \pm 0.28 \mathrm{~d}$ \\
\hline 50 & $\mathrm{NH}_{4}^{+}$ & Female & $8.44 \pm 0.95 \mathrm{cde}$ & $63.10 \pm 4.61 \mathrm{c}$ & $58.33 \pm 4.46 \mathrm{a}$ & $1.35 \pm 0.06 \mathrm{c}$ & $0.757 \pm 0.01 \mathrm{~d}$ & $13.88 \pm 1.59 \mathrm{~d}$ & $42.10 \pm 2.53 \mathrm{e}$ & $10.75 \pm 1.09 b$ & $0.784 \pm 0.06 \mathrm{de}$ & $4.57 \pm 0.31 \mathrm{~d}$ \\
\hline \multirow[t]{8}{*}{50} & $\mathrm{NH}_{4}^{+}$ & Male & $6.64 \pm 1.02 \mathrm{f}$ & $45.93 \pm 2.18 \mathrm{~d}$ & $53.06 \pm 2.40 \mathrm{~b}$ & $1.41 \pm 0.01 \mathrm{a}$ & $0.790 \pm 0.01 \mathrm{~b}$ & $24.18 \pm 2.16 \mathrm{c}$ & $58.68 \pm 2.64 \mathrm{c}$ & $7.39 \pm 0.92 \mathrm{~cd}$ & $1.01 \pm 0.14 \mathrm{c}$ & $3.25 \pm 0.40 \mathrm{e}$ \\
\hline & & $P_{\mathrm{se}}$ & $* * *$ & $* * *$ & $* *$ & $* * *$ & $\mathrm{~ns}$ & $* * *$ & $* * *$ & $* * *$ & $* * *$ & $* * *$ \\
\hline & & $P_{\mathrm{sa}}$ & $* * *$ & $* * *$ & $* * *$ & ns & $* * *$ & $* * *$ & $* * *$ & $* * *$ & ns & $* * *$ \\
\hline & & $P_{\mathrm{n}}$ & $* * *$ & $* * *$ & $\mathrm{~ns}$ & $\mathrm{~ns}$ & $\mathrm{~ns}$ & $* * *$ & $* * *$ & ns & $* * *$ & $* * *$ \\
\hline & & $P_{\mathrm{se} \times \mathrm{sa}}$ & $* * *$ & $*$ & $* * *$ & $* * *$ & $* * *$ & $* *$ & $* *$ & $* * *$ & $* * *$ & $* *$ \\
\hline & & $P_{\mathrm{se} \times \mathrm{n}}$ & Ns & ns & ns & $* * *$ & ns & ns & ns & ns & $* * *$ & $* * *$ \\
\hline & & $P_{\mathrm{sa} \times \mathrm{n}}$ & Ns & $* *$ & Ns & $\mathrm{ns}$ & ns & $\mathrm{ns}$ & ns & $*$ & $* * *$ & $* * *$ \\
\hline & & $P_{\mathrm{se} \times \mathrm{sa} \times \mathrm{n}}$ & Ns & ns & $*$ & ns & $* *$ & $* * *$ & ns & $* * *$ & $* * *$ & $*$ \\
\hline
\end{tabular}


Leaf biomass $(\mathrm{g})$; leaf area $\left(\mathrm{cm}^{2}\right) ; L M A\left(\mathrm{~g} \mathrm{~m}^{-2}\right)$, leaf dry mass per unit leaf area; leaf CC (g glucose $\left.\mathrm{g}^{-1}\right)$, leaf construction cost; $F_{\mathrm{v}} / F_{\mathrm{m}}$, maximum quantum efficiency of PSII photochemistry; $J\left(\mu \mathrm{mol} \mathrm{m} \mathrm{m}^{-2} \mathrm{~s}^{-1}\right)$, photosynthetic electron transport rate from chlorophyll fluorescence (Eq. 2); $V_{\mathrm{cmax}}$

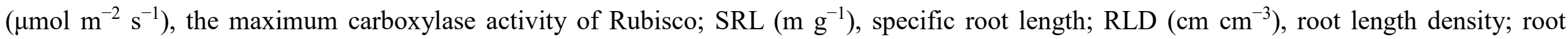
biomass $(\mathrm{g}) . P_{\mathrm{se}}$, sex effect; $P_{\mathrm{sa}}$, salt effect; $P_{\mathrm{n}}, \mathrm{N}$ form effect $\left(\mathrm{NO}_{3}{ }^{-}\right.$and $\left.\mathrm{NH}_{4}{ }^{+}\right) ; P_{\mathrm{se} \times \mathrm{sa}}$, the interaction effect of sex and salt stress; $P_{\mathrm{n} \times \mathrm{sa}}$, the interaction effect of $\mathrm{N}$ forms and salt stress; $P_{\mathrm{se} \times \mathrm{n}}$, the interaction effect of sex and $\mathrm{N}$ forms; $P_{\mathrm{se} \times \mathrm{n} \times \mathrm{sa}}$, the interaction effect of sex, $\mathrm{N}$ forms and salt stress. Different letters indicate significant differences between treatments $(P<0.05$, three-way ANOVA followed by Duncan's tests). Data are mean $\pm \mathrm{SE}(n=4)$. The significance values are shown as follows: $\mathrm{ns}$, not significant; $* 0.01<P \leq 0.05 ; * * 0.001<P \leq 0.01 ; * * * P \leq 0.001$ 
Table 2 Leaf thickness and anatomical traits in P. cathayana females and males grown under $\mathrm{NO}_{3}{ }^{-}$or $\mathrm{NH}_{4}{ }^{+}$supply, and with or without salt stress. Data are mean $\pm \operatorname{SE}(n=4)$.

\begin{tabular}{|c|c|c|c|c|c|c|c|c|c|c|c|c|c|}
\hline Salt & $\begin{array}{l}\mathrm{N} \\
\text { form }\end{array}$ & Sex & $f_{\text {ias }}(\%)$ & $S_{\mathrm{m}} / S$ & $S_{\mathrm{c}} / S$ & $S / W$ & $T_{1}$ & $T_{\mathrm{cw}}$ & $D_{\text {chl }}$ & $L_{\mathrm{chl}}$ & $T_{\mathrm{chl}}$ & $\Delta L_{\mathrm{cyt}, 1}$ & $\Delta L_{\mathrm{cyt} 2}$ \\
\hline 0 & $\mathrm{NO}_{3}^{-}$ & Female & $28.21 \pm 0.93 \mathrm{a}$ & $9.60 \pm 0.77 \mathrm{ab}$ & $7.36 \pm 0.99 \mathrm{bc}$ & $71.5 \pm 6.0 \mathrm{~b}$ & $171.3 \pm 3.2 \mathrm{~b}$ & $0.139 \pm 0.004 d$ & $12.8 \pm 0.9 \mathrm{~cd}$ & $5.9 \pm 0.6 \mathrm{ab}$ & $1.7 \pm 0.09 \mathrm{c}$ & $0.106 \pm 0.13 \mathrm{e}$ & $0.864 \pm 0.040 \mathrm{e}$ \\
\hline 0 & $\mathrm{NO}_{3}^{-}$ & Male & $28.28 \pm 1.67 \mathrm{a}$ & $7.76 \pm 0.22 \mathrm{c}$ & $7.01 \pm 0.24 \mathrm{c}$ & $35.6 \pm 4.7 \mathrm{~d}$ & $220.6 \pm 17.8 \mathrm{a}$ & $0.123 \pm 0.001 \mathrm{e}$ & $16.3 \pm 1.0 \mathrm{a}$ & $6.1 \pm 0.6 \mathrm{a}$ & $1.3 \pm 0.06 \mathrm{e}$ & $0.093 \pm 0.002 \mathrm{e}$ & $0.821 \pm 0.004 \mathrm{e}$ \\
\hline 0 & $\mathrm{NH}_{4}^{+}$ & Female & $22.35 \pm 1.78 b$ & $10.04 \pm 0.36 \mathrm{a}$ & $7.98 \pm 0.63 \mathrm{ab}$ & $72.9 \pm 0.91 b$ & $177.8 \pm 8.8 \mathrm{~b}$ & $0.144 \pm 0.004 d$ & $11.5 \pm 0.6 \mathrm{~d}$ & $4.7 \pm 0.6 \mathrm{c}$ & $1.7 \pm 0.06 \mathrm{c}$ & $0.138 \pm 0.10 \mathrm{~d}$ & $0.969 \pm 0.025 \mathrm{~d}$ \\
\hline 0 & $\mathrm{NH}_{4}^{+}$ & Male & $23.90 \pm 2.58 \mathrm{~b}$ & $8.54 \pm 0.66 \mathrm{bc}$ & $8.45 \pm 0.65 b c$ & $42.5 \pm 5.7 \mathrm{~d}$ & $216.1 \pm 44.2 \mathrm{a}$ & $0.116 \pm 0.007 \mathrm{e}$ & $13.8 \pm 1.0 \mathrm{bc}$ & $6.2 \pm 0.5 \mathrm{a}$ & $1.6 \pm 0.09 \mathrm{~cd}$ & $0.074 \pm 0.003 \mathrm{f}$ & $0.877 \pm 0.034 \mathrm{e}$ \\
\hline 50 & $\mathrm{NO}_{3}^{-}$ & Female & $18.14 \pm 0.74 \mathrm{c}$ & $6.93 \pm 0.46 \mathrm{~d}$ & $5.93 \pm 0.69 \mathrm{~d}$ & $82.7 \pm 1.5 \mathrm{a}$ & $177.3 \pm 1.9 \mathrm{~b}$ & $0.171 \pm 0.004 b$ & $8.8 \pm 1.0 \mathrm{e}$ & $5.2 \pm 0.6 \mathrm{bc}$ & $2.6 \pm 0.2 b$ & $0.202 \pm 0.016 \mathrm{~b}$ & $1.38 \pm 0.042 b$ \\
\hline 50 & $\mathrm{NO}_{3}^{-}$ & Male & $22.90 \pm 2.62 b$ & $8.40 \pm 1.09 \mathrm{bc}$ & $6.31 \pm 0.75 \mathrm{c}$ & $52.5 \pm 8.9 \mathrm{c}$ & $212.3 \pm 2.7 \mathrm{a}$ & $0.160 \pm 0.007 \mathrm{c}$ & $16.3 \pm 1.3 \mathrm{a}$ & $5.9 \pm 0.2 \mathrm{ab}$ & $1.4 \pm 0.05 \mathrm{de}$ & $0.162 \pm 0.016 \mathrm{c}$ & $1.02 \pm 0.058 \mathrm{~d}$ \\
\hline 50 & $\mathrm{NH}_{4}^{+}$ & Female & $14.49 \pm 0.67 \mathrm{~d}$ & $6.22 \pm 0.16 \mathrm{~d}$ & $4.96 \pm 0.63 \mathrm{e}$ & $89.2 \pm 2.6 \mathrm{a}$ & $177.6 \pm 3.9 b$ & $0.203 \pm 0.009 \mathrm{a}$ & $9.0 \pm 0.8 \mathrm{e}$ & $5.2 \pm 0.5 \mathrm{bc}$ & $3.2 \pm 0.3 \mathrm{a}$ & $0.279 \pm 0.018 \mathrm{a}$ & $1.59 \pm 0.11 \mathrm{a}$ \\
\hline \multirow[t]{8}{*}{50} & $\mathrm{NH}_{4}^{+}$ & Male & $23.29 \pm 2.55 b$ & $8.97 \pm 1.45 \mathrm{abc}$ & $7.13 \pm 0.68 \mathrm{c}$ & $41.0 \pm 4.4 \mathrm{~d}$ & $212.5 \pm 9.2 \mathrm{a}$ & $0.137 \pm 0.005 \mathrm{~d}$ & $14.5 \pm 0.6 \mathrm{~b}$ & $6.3 \pm 0.5 \mathrm{a}$ & $1.6 \pm 0.1 \mathrm{~cd}$ & $0.218 \pm 0.007 \mathrm{~b}$ & $1.22 \pm 0.078 \mathrm{c}$ \\
\hline & & $P_{\mathrm{se}}$ & $* * *$ & ns & $* * *$ & $* * *$ & $* * *$ & $* * *$ & $* * *$ & $* * *$ & $* * *$ & $* * *$ & $* * *$ \\
\hline & & $P_{\mathrm{sa}}$ & $* * *$ & $* * *$ & $* * *$ & $* * *$ & $\mathrm{~ns}$ & $* * *$ & $* * *$ & $\mathrm{~ns}$ & $* * *$ & $* * *$ & $* * *$ \\
\hline & & $P_{\mathrm{n}}$ & $* * *$ & $\mathrm{~ns}$ & ns & ns & $\mathrm{ns}$ & $\mathrm{ns}$ & $* * *$ & ns & $* * *$ & $* * *$ & $* * *$ \\
\hline & & $P_{\mathrm{se} \times \mathrm{sa}}$ & $* * *$ & $* * *$ & ns & ns & ns & $* * *$ & $* * *$ & ns & $* * *$ & ns & $* * *$ \\
\hline & & $P_{\mathrm{se} \times \mathrm{n}}$ & $* * *$ & $\mathrm{~ns}$ & $\mathrm{~ns}$ & $*$ & $\mathrm{~ns}$ & $* * *$ & $*$ & $*$ & ns & $* * *$ & ns \\
\hline & & $P_{\mathrm{sa} \times \mathrm{n}}$ & $* * *$ & $\mathrm{~ns}$ & $\mathrm{~ns}$ & $*$ & ns & $\mathrm{ns}$ & $\mathrm{ns}$ & ns & $*$ & $* * *$ & $* *$ \\
\hline & & $P_{\mathrm{se} \times \mathrm{sa} \times \mathrm{n}}$ & Ns & $\mathrm{ns}$ & $*$ & $* * *$ & $\mathrm{~ns}$ & $* * *$ & ns & ns & $* *$ & ns & ns \\
\hline
\end{tabular}


$f_{\text {ias }}(\%)$, the volume fraction of intercellular air space per unit leaf area; $S_{\mathrm{m}} / S\left(\mathrm{~m}^{2} \mathrm{~m}^{-2}\right)$, mesophyll surface area exposed to intercellular air space per unit leaf area; $S_{\mathrm{c}} / S\left(\mathrm{~m}^{2} \mathrm{~m}^{-2}\right)$, chloroplast surface area exposed to intercellular air space per unit leaf area; $S / W\left(\mu \mathrm{m}^{2} \mu \mathrm{m}^{-1}\right)$, mesophyll cell area per transverse section width; $T_{1}(\mu \mathrm{m})$, leaf thickness; $T_{\mathrm{cw}}(\mu \mathrm{m})$, cell wall thickness; $D_{\mathrm{chl}}$ (no. no), chloroplast density; $L_{\mathrm{chl}}(\mu \mathrm{m})$, chloroplast length; $T_{\mathrm{chl}}(\mu \mathrm{m})$, chloroplast thickness; $\Delta L_{\mathrm{cyt}, 1}(\mu \mathrm{m})$, the vertical distance between the chloroplasts and cell walls; $\Delta L_{\mathrm{cyt} 2}(\mu \mathrm{m})$, the distance between the neighboring chloroplasts. $P_{\text {se, }}$, sex effect; $P_{\text {sa }}$, salt effect; $P_{\mathrm{n}}, \mathrm{N}$ form effect $\left(\mathrm{NO}_{3}{ }^{-}\right.$and $\left.\mathrm{NH}_{4}{ }^{+}\right) ; P_{\text {se } \times \text { sa }}$, the interaction effect of sex and salt stress; $P_{\mathrm{n} \times \mathrm{sa}}$, the interaction effect of $\mathrm{N}$ forms and salt stress; $P_{\mathrm{se} \times \mathrm{n}}$, the interaction effect of sex and N forms; $P_{\mathrm{se} \times \mathrm{n} \times \mathrm{sa}}$, the interaction effect of sex, $\mathrm{N}$ forms and salt stress. Different letters indicate significant differences between treatments $(P<0.05$, three-way ANOVA followed by Duncan's tests). Data are mean $\pm \operatorname{SE}(n=4)$. The significance values are shown as follows: ns, not significant; $* 0.01<P \leq 0.05 ; * * 0.001<P \leq$ $0.01 ; * * * P \leq 0.001$ 